\title{
Ethanolic Extract of Senna velutina Roots: Chemical Composition, In Vitro and In Vivo Antitumor Effects, and B16F10-Nex2 Melanoma Cell Death Mechanisms
}

\author{
David Tsuyoshi Hiramatsu Castro, ${ }^{1}$ Jaqueline Ferreira Campos, ${ }^{1}$ Marcio José Damião, ${ }^{1}$ \\ Heron Fernandes Vieira Torquato, ${ }^{2}$ Edgar Julian Paredes-Gamero, ${ }^{2,3}$ \\ Carlos Alexandre Carollo $₫$, ${ }^{4}$ Elaine Guadelupe Rodrigues, ${ }^{5}$ Kely de Picoli Souza $\mathbb{B}^{1},{ }^{1}$ \\ and Edson Lucas dos Santos $\mathbb{D}^{1}$ \\ ${ }^{1}$ Research Group on Biotechnology and Bioprospecting Applied to Metabolism (GEBBAM), Federal University of Grande Dourados, \\ Dourados, CEP: 79804-970 MS, Brazil \\ ${ }^{2}$ Department of Biochemistry, Federal University of São Paulo, São Paulo, CEP: 04044-020, SP, Brazil \\ ${ }^{3}$ Faculty of Pharmaceutical Sciences, Food and Nutrition, Federal University of Mato Grosso do Sul, Campo Grande, CEP: 79070-900, \\ MS, Brazil \\ ${ }^{4}$ Laboratory of Natural Products and Mass Spectrometry, Federal University of Mato Grosso do Sul, Campo Grande, \\ CEP: 79070-900 MS, Brazil \\ ${ }^{5}$ Department of Microbiology, Immunology, and Parasitology, Paulista School of Medicine, Federal University of São Paulo (EPM- \\ UNIFESP), São Paulo, CEP: 04023-062 SP, Brazil
}

Correspondence should be addressed to Edson Lucas dos Santos; edsonsantosphd@gmail.com

Received 7 December 2018; Revised 18 April 2019; Accepted 24 April 2019; Published 12 June 2019

Guest Editor: Patrícia Rijo

Copyright ( 2019 David Tsuyoshi Hiramatsu Castro et al. This is an open access article distributed under the Creative Commons Attribution License, which permits unrestricted use, distribution, and reproduction in any medium, provided the original work is properly cited.

\footnotetext{
Cutaneous melanoma is among the most aggressive types of cancer, and its rate of occurrence increases every year. Current pharmacological treatments for melanoma are not completely effective, requiring the identification of new drugs. As an alternative, plant-derived natural compounds are described as promising sources of new anticancer drugs. In this context, the objectives of this study were to identify the chemical composition of the ethanolic extract of Senna velutina roots (ESVR), to assess its in vitro and in vivo antitumor effects on melanoma cells, and to characterize its mechanisms of action. For these purposes, the chemical constituents were identified by liquid chromatography coupled to high-resolution mass spectrometry. The in vitro activity of the extract was assessed in the B16F10-Nex2 melanoma cell line using the 3-(4,5-dimethylthiazol-2-yl)-2,5-diphenyltetrazolium bromide (MTT) assay and based on the apoptotic cell count; DNA fragmentation; necrostatin-1 inhibition; intracellular calcium, pan-caspase, and caspase-3 activation; reactive oxygen species (ROS) levels; and cell cycle arrest. The in vivo activity of the extract was assessed in models of tumor volume progression and pulmonary nodule formation in C57Bl/6 mice. The chemical composition results showed that ESVR contains flavonoid derivatives of the catechin, anthraquinone, and piceatannol groups. The extract reduced B16F10-Nex2 cell viability and promoted apoptotic cell death as well as caspase-3 activation, with increased intracellular calcium and ROS levels as well as cell cycle arrest at the sub- $\mathrm{G}_{0} / \mathrm{G}_{1}$ phase. In vivo, the tumor volume progression and pulmonary metastasis of ESVR-treated mice decreased over 50\%. Combined, these results show that ESVR had in vitro and in vivo antitumor effects, predominantly by apoptosis, thus demonstrating its potential as a therapeutic agent in the treatment of melanoma and other types of cancer.
} 


\section{Introduction}

Cancer is among the leading causes of death worldwide [1]. In particular, cutaneous melanoma is a potentially lethal form of skin cancer and occurs when melanocytes, cells responsible for producing the melanin pigment, undergo changes mediated by endogenous and/or exogenous events, thereby becoming malignant $[2,3]$. The main factors responsible for the onset of melanoma are intrinsic and extrinsic. Intrinsic factors primarily include genetic susceptibility and family history, whereas the main extrinsic factor is excessive exposure to ultraviolet radiation $[4,5]$.

In recent decades, the incidence of cutaneous melanoma has increased, and according to the World Health Organization, approximately 132,000 cases of melanoma are diagnosed every year worldwide [6]. Its incidence varies among different populations, and the highest rates are reported in countries such as Australia and New Zealand [7]. When melanoma is detected early, surgical removal increases the treatment efficacy in approximately $99 \%$ of cases [8]. Chemotherapy, immunotherapy, and molecular therapy are among the main treatments for melanoma $[9,10]$. Although patient survival rates are increasing, therapies and their combinations are still limited because they cause toxicity [11]. In addition, advanced-stage melanoma is resistant to drug therapy [12].

As an alternative to current therapies, phytochemical molecules have gained prominence as promising agents for the development of new drugs in the treatment of neoplasia [13]. Some studies have demonstrated that these substances show low toxicity in normal cells and act as melanoma treatment adjuvants, enhancing the anticancer effects of chemotherapeutic agents $[14,15]$.

In the scientific literature, the anticancer properties of more than 3000 plant species have been described [16]. Furthermore, in the last 70 years, 175 anticancer molecules were approved by the Food and Drug Administration (FDA), and 85 of them are derived from natural products or their derivatives [17].

These molecules, known as secondary metabolites, are complex compounds with diverse structures responsible for various biological activities [18]. These characteristics, together with the high degree of biodiversity in Brazil, may provide a promising source of new drugs. The genus Senna (Fabaceae) is found in the Brazilian Cerrado and has more than 250 species whose antimicrobial [19], antidiabetic [20], antioxidant [21], anti-inflammatory [22], and anticancer [23-25] properties have been described.

The species Senna velutina, a shrub of the genus Senna, commonly known as São João, vermelhinho, or Fedegosodo-Cerrado, is found in the Central-West, Southeast, and Northeast regions of Brazil [26, 27]. Although the species is used by the population for medicinal purposes, only one article has described the antileukemic activity of the leaves of this plant [24]. However, no scientific study has described the chemical constituents and anticancer properties of the roots of this plant. In this context, the objective of this study was to characterize the chemical composition, assess the in vitro and in vivo antitumor effects, and identify the mechanisms through which the ethanolic extract of $S$. velutina roots (ESVR) promotes B16F10-Nex2 melanoma cell death.

\section{Materials and Methods}

2.1. Plant Material and Extract Preparation. S. velutinaroots were collected in the Cerrado region (Brazilian biome), in the state of Mato Grosso do Sul (S $22^{\circ} 05^{\prime} 545^{\prime \prime}$ and W $055^{\circ} 20^{\prime}$ $\left.746^{\prime \prime}\right)$, in the Central-West region of Brazil and identified by a botanist. A dried sample of the species was deposited in the Herbarium of the Federal University of Grande Dourados-UFGD, Dourados, Mato Grosso do Sul (MS), Brazil, with registration number 4665 . Root collection was authorized by the Sistema de Autorização e Informação em Biodiversidade (Biodiversity Information and Authorization System; SISBIO, permit number 54470-1). Subsequently, the plant roots were rinsed, dried in an air circulation oven for 15 days at $36^{\circ} \mathrm{C}$, and pulverized; $200 \mathrm{~g}$ was then macerated in $95 \%$ ethanol $(7: 1)$ at room temperature for 7 days. Then, the extract was filtered and the residue was subjected to the same procedure twice. After 21 days, the filtrate was concentrated in a rotary vacuum evaporator (Gehaka, São Paulo, SP, Brazil) and subsequently freeze-dried (model Savant MicroModulyo, Thermo Fisher Scientific, Massachusetts, EUA). The dry extract yield was $23 \%$, calculated using the following formula: extraction yield $(\%)=$ (weight of the freeze - dried extract $\times 100) /($ weight of the original sample $)$. The ESVR was stored at $-20^{\circ} \mathrm{C}$ for subsequent experiments.

2.2. Phytochemical Analysis. ESVR was analyzed in an ultrafast liquid chromatograph (UFLC, Shimadzu) coupled to a diode array detector (DAD, Shimadzu) and electrospray ionization time-of-flight mass spectrometer (ESI-QTOF-micrOTOF QII, Bruker Daltonics; operating in the positive and negative ionization modes, $120-1200 \mathrm{Da}$ ). A C-18 column was used (Kinetex, $2.6 \mu \mathrm{m}, 150 \times 2.2 \mathrm{~mm}$, Phenomenex), protected by a guard precolumn of the same material. The mobile phase was water (solvent $\mathrm{A}$ ) and acetonitrile (solvent B), both with $0.1 \%$ formic acid, in a gradient of $0-2 \mathrm{~min} 3 \% \mathrm{~B}, 2-25 \mathrm{~min} 3-25 \% \mathrm{~B}$, and 25-40 min $25-80 \% \mathrm{~B}$, followed by the washing and reconditioning of the columns $(8 \mathrm{~min})$. The flow rate was $0.3 \mathrm{~mL} / \mathrm{min}$, and $1 \mu \mathrm{L}$ of the extract $(1 \mathrm{mg} / \mathrm{mL})$ was injected. The other micrOTOF QII parameters were as follows: temperature, $200^{\circ} \mathrm{C} ; \mathrm{N}_{2}$ gas flow rate, $9 \mathrm{~L} / \mathrm{min}$; nebulizer, 4.0 bar; capillary voltage, $3500 \mathrm{~V}$ (negative), $+4500 \mathrm{~V}$ (positive); and internal calibration with sodium trifluoroacetate (TFA-Na) injected at the end of the chromatographic analysis. The catechin and piceatannol authentic standards were purchased from Sigma-Aldrich with $\geq 95 \%$ purity. The metabolites present in ESVR were identified based on the interpretation of mass and UV absorption spectra and based on comparison with the literature. When available, the compounds were confirmed by comparison with authentic standards.

2.3. Cell Lines and Cell Cultures. Human peripheral blood mononuclear cells (PBMCs) were collected after donor consent. Mononuclear cells were separated by centrifugation using Ficoll Histopaque-1077 (1.077 g/ $\left.\mathrm{cm}^{3}\right)$ (Sigma-Aldrich, Germany) according to the manufacturer's instructions at $400 \times \mathrm{g}$ for $30 \mathrm{~min}$. The use of human blood was approved by the Ethics Committee of the Federal University of Grande Dourados (UFGD) under protocol 123/12. The murine melanoma subline (B16F10-Nex2) was isolated at the Oncology Experimental 
Unit (Federal University of São Paulo, UNIFESP) from the B16F10 cell line and cultured in RPMI 1640 medium (Gibco/Invitrogen, Minneapolis, MN) supplemented with 4-(2-hydroxyethyl)piperazine-1-ethanesulfonic acid (HEPES, $10 \mathrm{nM})$ and sodium bicarbonate $(24 \mathrm{nM})$. Human lung fibroblasts (MRC-5) and human melanoma cell lines (SK-Mel-28 and SK-Mel-103) were cultured in high-glucose Dulbecco's Modified Eagle's Medium (DMEM). All cell lines were supplemented with $10 \%$ fetal bovine serum (FBS, purchased from Gibco/Invitrogen) and $40 \mathrm{mg} / \mathrm{mL}$ gentamicin (Hipolabor Farmacêutica, Sabará, MG, Brazil). They were kept in flasks at $37^{\circ} \mathrm{C}$ in $5 \% \mathrm{CO}_{2}$.

2.4. MTT Cell Viability Assay. The cell viability was assessed using the 3-(4,5-diphenyltetrazolium-2-yl)-2,5-diphenyltrazolium bromide (MTT) colorimetric assay. Adherent cells were plated at a density of $5 \times 10^{3}$ cells/well, and PBMCs were plated at $10^{5}$ cells/well in 96-well microtiter plates. After 24 and $48 \mathrm{~h}$, solutions with different ESVR concentrations (25$125 \mu \mathrm{g} / \mathrm{mL}$ ), diluted in medium with $0.1 \%$ DMSO, were added, and medium with only $0.1 \%$ DMSO was used as a control. At the end of both periods, $100 \mu \mathrm{L} \mathrm{MTT}(0.5 \mathrm{mg} / \mathrm{mL})$ was added to each well. The cell culture was incubated for another $4 \mathrm{~h}$, and $100 \mu \mathrm{L}$ of DMSO was then added to solubilize the formazan crystals. The absorbance was determined at $570 \mathrm{~nm}$ using a SpectraMax 250 reader (Molecular Devices). Cell viability inhibition was calculated using the following formula:

$$
\text { Cell viability }(\%)=\left[\mathrm{Abs}_{\text {treated cells }} / \mathrm{Abs}_{\mathrm{control}}\right] \times 100 \text {. }
$$

2.5. Effect of ESVR on B16F10-Nex2 Cells. B16F10-Nex2 cells $\left(5 \times 10^{3}\right.$ cells/well $)$ were subjected to solutions with different ESVR concentrations $(25-125 \mu \mathrm{g} / \mathrm{mL})$ diluted in RPMI 1640 solution with $0.1 \%$ DMSO for $24 \mathrm{~h}$. RPMI 1640 solution with $0.1 \%$ DMSO was used as a control. Subsequently, cell images were acquired under a Nikon TE2000E (Nikon Instruments Inc.) microscope (10x objective).

2.6. Cell Death Profile. The cell death profile was determined using the method described by Paredes-Gamero et al. in 2012 [28] with a few modifications. B16F10-Nex2 cells were plated in 48-well plates ( $10^{4}$ cells/well) and cultured in RPMI 1640 with $10 \%$ FBS for $24 \mathrm{~h}$ as well as with the half-maximal inhibitory concentration $\left(\mathrm{IC}_{50}\right)$ of $\operatorname{ESVR}(52 \mu \mathrm{g} / \mathrm{mL})$. After this period, the cells were washed with phosphate-buffered saline (PBS), detached, and resuspended in buffer solution $(0.01 \mathrm{M}$ HEPES, $\mathrm{pH}=7.4,0.14 \mathrm{M} \mathrm{NaCl}$, and $2.5 \mathrm{mM} \mathrm{CaCl}_{2}$ ). The suspension was labeled with annexin $\mathrm{V}$-fluorescein isothiocyanate (FITC) and propidium iodide (Becton Dickinson, USA) according to the manufacturer's instructions. The cells were incubated with the $\mathrm{IC}_{50}$ concentration of ESVR diluted in the medium to assess whether the extract showed fluorescence under the study parameters. The cells were incubated for $15 \mathrm{~min}$ at room temperature, and subsequently, 10,000 events per sample were collected and analyzed in the Accuri $^{\mathrm{TM}}$ C6 flow cytometer (Becton Dickinson, USA) using the software FlowJo v10.2 LCC (Oregon, USA).
2.7. Apoptotic B16F10-Nex2 Cell Nuclei Count. To count the apoptotic cell nuclei, $6 \times 10^{4} \mathrm{~B} 16 \mathrm{~F} 10-\mathrm{Nex} 2$ cells/well were plated on coverslips in 24-well plates. Subsequently, the cells were treated with $52 \mu \mathrm{g} / \mathrm{mL}$ ESVR diluted in RPMI 1640 solution with $0.1 \%$ DMSO for $24 \mathrm{~h}$. As a control, RPMI 1640 solution with $0.1 \%$ DMSO was used. After this period, the supernatant was discarded, and the cells were washed with PBS twice and fixed with $2 \%$ paraformaldehyde for $20 \mathrm{~min}$ at room temperature. Then, the cells were washed with PBS and permeabilized with $0.01 \%$ saponin for $20 \mathrm{~min}$.

To detect apoptotic nuclei, coverslips were placed on slides and labeled with $4^{\prime}-6^{\prime}$-diamidino-2-phenylindole (DAPI) dihydrochloride. Cells were counted under a LEICA DMI 6000B confocal microscope (Leica Microsystems, Germany).

2.8. DNA Fragmentation. B16F10-Nex2 cells were plated at $1 \times 10^{6}$ cells/well. After $24 \mathrm{~h}$, the cells were treated with $52 \mu \mathrm{g} / \mathrm{mL}$ ESVR diluted in RPMI 1640 solution with $0.1 \%$ DMSO. RPMI 1640 solution with $0.1 \%$ DMSO was used as a control for 12 and $24 \mathrm{~h}$. Subsequently, the DNA was extracted with phenol/chloroform, followed by incubation with RNAse $(20 \mu \mathrm{g} / \mathrm{mL})$. The DNA integrity was visualized in a $2.5 \%$ agarose gel stained with ethidium bromide $(0.5 \mu \mathrm{g} / \mathrm{mL})$.

2.9. Caspase-3 Activity. Caspase-3 activation was assessed by flow cytometry according to the method described by Moraes et al. in 2013 [29] with minor modifications. B16F10-Nex2 cells $\left(6 \times 10^{4}\right.$ cells/well $)$ were treated with $\operatorname{ESVR}(52 \mu \mathrm{g} / \mathrm{mL})$ and diluted in RPMI 1640 solution with 0.1\% DMSO for $24 \mathrm{~h}$. RPMI 1640 solution with $0.1 \%$ DMSO was used as a control. After the treatment, the cells were fixed with $2 \%$ paraformaldehyde for $30 \mathrm{~min}$ and then permeabilized with $0.01 \%$ saponin in PBS for $20 \mathrm{~min}$ at room temperature. Subsequently, the cells were incubated for $1 \mathrm{~h}$ with cleaved caspase- 3 (Asp175) antibody (Alexa Fluor ${ }^{\circledR} 488$ conjugate) at room temperature and protected from light. After the incubation period, the fluorescence was acquired in 10,000 events in the Accuri C6 flow cytometer (Becton Dickinson, San Jose, CA) and analyzed using the software FlowJo v8.7 (Ashland, USA).

2.10. Determination of the Reactive Oxygen Species (ROS) Levels. ROS levels were determined by flow cytometry using the $2^{\prime}, 7^{\prime}$-dichlorodihydrofluorescein diacetate ( $\left.\mathrm{H}_{2} \mathrm{DCFDA}\right)$ dye (Molecular Probe-Life Technologies, Carlsbad, CA). For this purpose, B16F10-Nex 2 cells $\left(6 \times 10^{4}\right.$ cells/well $)$ were treated for $24 \mathrm{~h}$ with ESVR $(52 \mu \mathrm{g} / \mathrm{mL})$ diluted in RPMI 1640 solution with $0.1 \%$ DMSO, and RPMI 1640 solution with $0.1 \%$ DMSO was used as a control. Subsequently, the cells were trypsinized and incubated with $10 \mu \mathrm{M} \mathrm{H} \mathrm{H}_{2}$ DCFDA for $30 \mathrm{~min}$ at room temperature and protected from light. After the incubation period, the fluorescence, related to the ROS levels, was acquired in 15,000 events in the Accuri C6 flow cytometer (Becton Dickinson, San Jose, CA) and analyzed using the software FlowJo v8.7. (Ashland, US).

2.11. Pan-Caspase, Intracellular Calcium, and Necrostatin-1 Inhibition. To assess the involvement of caspases, intracellular calcium, and RIPK1 in ESVR-promoted cell death, B16F10-Nex2 cells $\left(5 \times 10^{3}\right.$ cells/well) were pretreated for 
$1 \mathrm{~h}$ with carbobenzoxy-valyl-alanyl-aspartyl-(O-methyl)-fluoromethylketone (Z-VAD-FMK; irreversible, cell-permeant pancaspase inhibitor), 1,2-bis(2-aminophenoxy)ethane-N,N, ${ }^{\prime}$, $\mathrm{N}^{\prime}$-tetraacetic acid tetra(acetoxymethyl ester) (BAPTA-AM; cell-permeant calcium chelator), or necrostatin-1 (NEC-1) inhibitor. Then, the cells were treated with ESVR $(52 \mu \mathrm{g} / \mathrm{mL})$ diluted in RPMI 1640 solution with $0.1 \%$ DMSO for $24 \mathrm{~h}$. RPMI 1640 solution with $0.1 \%$ DMSO was used as a control. After this period, the cell viability was determined using the MTT assay, which was previously described in Section 2.4 .

2.12. Cell Cycle Phases. The distribution of cell cycle phases was assessed using the method described by ParedesGamero et al. in 2012 [28]. For this purpose, B16F10Nex2 cells $\left(6 \times 10^{4}\right.$ cells/well $)$ were treated with ESVR $\left(1 / 2 \mathrm{IC}_{50}=26 \mu \mathrm{g} / \mathrm{mL}\right.$ and $\left.\mathrm{IC}_{50}=52 \mu \mathrm{g} / \mathrm{mL}\right)$ diluted in RPMI 1640 solution with $0.1 \%$ DMSO for $24 \mathrm{~h}$. RPMI 1640 solution with $0.1 \%$ DMSO was used as a control. Subsequently, the cells were fixed and permeabilized as described above and incubated with RNAse ( $4 \mathrm{mg} / \mathrm{mL}$ ) (Sigma-Aldrich, Germany) for $1 \mathrm{~h}$ at $37^{\circ} \mathrm{C}$. For DNA labeling, the cells were incubated with SYTOX Green $(5 \mu \mathrm{g} / \mathrm{mL})$ (Molecular Probes Inc., Oregon). The percentage of cells at each cell cycle phase (sub- $G_{0 /} G_{1}, S$, and $G_{2} / M$ ) was determined in 40,000 events in an Accuri C6 flow cytometer (Becton Dickinson, San Jose, CA). The results were analyzed using the software FlowJo v.8.7.

2.13. Animals. Male C57Bl/6 mice 4-6 weeks of age were obtained from the Centro de Desenvolvimento de Modelos Experimentais para Medicina e Biologia (Center for the Development of Experimental Models for Medicine and Biology-Federal University of São Paulo (CEDEME-UNIFESP), São Paulo, Brazil). In all experiments, the "Principles of Laboratory Animal Care" guidelines were followed (National Institute of Health (NIH) publication Number 85-23, revised in 1985), and animal experimentation was performed using protocols approved by the Animal Ethics Committee of the Federal University of São Paulo (UNIFESP) under number 1234/11.

2.14. In Vivo Antitumor Assay. Previously cultured B16F10Nex 2 melanoma cells $\left(5 \times 10^{4}\right.$ cells/animals $)$ were subcutaneously implanted in the lumbosacral region of $\mathrm{C} 57 \mathrm{Bl} / 6$ mice (seven animals per group). From the second day of implantation, the mice were intraperitoneally injected with ESVR $(520 \mu \mathrm{g} / \mathrm{mL})$ every other day for 30 days. The dose chosen was 10 times higher than the $\mathrm{IC}_{50}$ observed in the in vitro assays. The mice from the control group were intraperitoneally injected with the vehicle RPMI 1640 with $0.1 \%$ DMSO. The tumor volume was monitored after the 16th day of treatment, and the tumor diameter was measured three times a week. The tumor volume was determined using the following formula:

$$
\begin{aligned}
\text { Tumor volume }\left(\mathrm{mm}^{3}\right)= & \text { larger diameter } \\
& \times \text { smaller diameter }{ }^{2} \times 0.52 .
\end{aligned}
$$

2.15. In Vivo Pulmonary Metastasis Evaluation. The experiment was conducted according to Pereira et al. in 2016 [30] with minor modifications. Thus, $5 \times 10^{5}$ B16F10Nex2 melanoma cells were injected through the caudal vein into $\mathrm{C} 57 \mathrm{Bl} / 6$ mice (five animals per group). From the second day of implantation, the mice were intraperitoneally injected with ESVR $(520 \mu \mathrm{g} / \mathrm{mL})$ every other day for 14 days. The mice from the control group were intraperitoneally injected with vehicle RPMI 1640 with $0.1 \%$ DMSO. On the 15th day, the mice were anesthetized and euthanized. The lungs were removed, and the lung nodules were counted using a stereoscope (Nikon SMZ745T), with the images recorded using a Ds-Fi2 camera.

2.16. Statistical Analysis. All data are expressed as the mean \pm standard error of the mean (SEM). The half-maximal inhibitory concentrations $\left(\mathrm{IC}_{50}\right)$ with confidence limits of 95\% were determined by nonlinear regression using the software GraphPad Prism 6 software (San Diego, CA, USA). Significant differences between groups were determined using the unpaired Student's $t$-test (in apoptotic B16F10-Nex2 cell count, caspase-3 activity, determination of ROS levels, cell cycle phase, in vivo antitumor assay, and in vivo pulmonary metastasis evaluation) for comparison between two groups and analysis of variance (ANOVA) followed by Dunnett's test for comparison of two or more groups (in pan-caspase, intracellular calcium, and necrostatin-1 inhibition) using the GraphPad Prism 5 software (San Diego, CA, USA). The results were considered significant when $p<0.05$.

\section{Results}

3.1. Phytochemical Composition of ESVR. Compounds relative to the twenty one chromatographic peaks were detected in the ethanolic extract of $S$. velutina roots, including sugar derivatives, gallocatechin, epigallocatechin, catechin, epicatechin, butiniflavan-(epi)gallocatechin, butiniflavan-(epi)catechin, piceatannol, cassiaflavan-(epi)gallocatechin, cassiaflavan(epi) catechin, and dimeric tetrahydroanthracene derivatives (Figure 1 and Table 1).

3.2. Cell Viability Assay. Figure 2 shows that B16F10-Nex2 cells were sensitive to ESVR in a concentration-dependent manner after $24 \mathrm{~h}\left(\mathrm{IC}_{50}\right.$ of $\left.52 \mu \mathrm{g} / \mathrm{mL}\right)$ and $48 \mathrm{~h}\left(\mathrm{IC}_{50}\right.$ of $59 \mu \mathrm{g} / \mathrm{mL}$ ) of treatment. In both treatment periods, the ESVR decreased the number of viable cells. On the other hand, ESVR cytotoxicity was lower in the PBMC and MRC-5 cell lines than in B16F10-Nex2 cells; it was observed that even after $48 \mathrm{~h}$ of incubation with the highest dose tested $(125 \mu \mathrm{g} / \mathrm{mL})$, the extract was cytotoxic to only $20-30 \%$ of the cells. Additionally, the effect of ESVR against human melanoma cell lines SK-Mel-28 ( $\mathrm{IC}_{50}$ of $420.21 \mu \mathrm{g} / \mathrm{mL}$ in $24 \mathrm{~h}$ and $330.48 \mu \mathrm{g} / \mathrm{mL}$ in $48 \mathrm{~h})$ and SK-Mel-103 (IC 50 of $245.23 \mu \mathrm{g} / \mathrm{L}$ in $24 \mathrm{~h}$ and $94.09 \mu \mathrm{g} / \mathrm{mL}$ in $48 \mathrm{~h}$ ) was evaluated (reported in supplementary Figure 1). However, in both SK-Mel cell lines the results were lower than those observed against B16F10-Nex2 cells. B16F10-Nex2 cells were chosen for the next analyses, since they were more sensitive to the action of ESVR. 


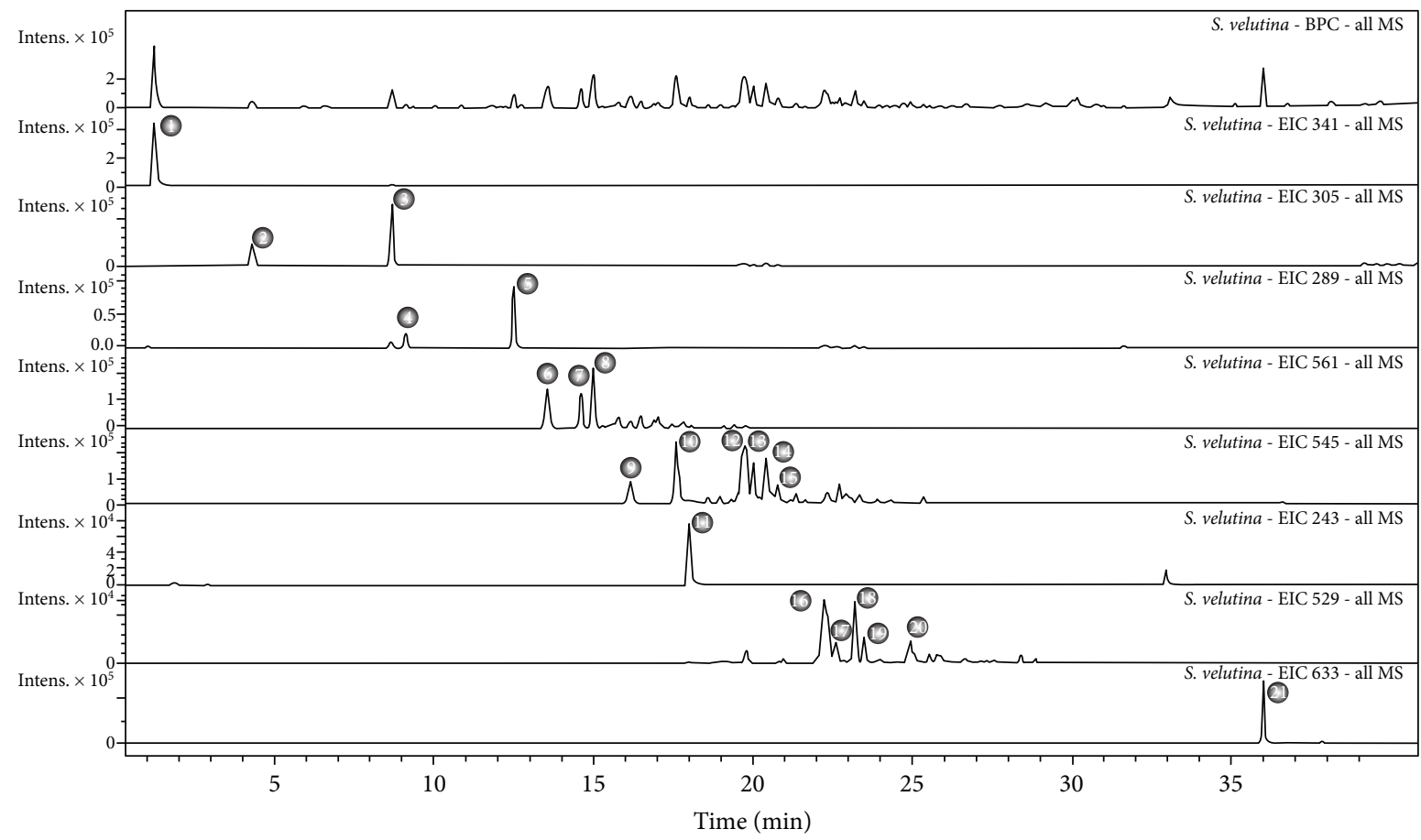

FIGURE 1: Characterization of the compounds identified in ESVR by UFLC-MS. Chromatograms with the base peaks and peaks identified in the extract.

TABLE 1: ESVR chemical profile as analyzed by UFLC-MS (negative mode).

\begin{tabular}{|c|c|c|c|c|c|c|c|}
\hline Peak & Retention time & UV & $\begin{array}{l}\text { Molecular } \\
\text { formula }\end{array}$ & $(\mathrm{M}-\mathrm{H})$ & $\begin{array}{l}\text { PPM } \\
\text { error }\end{array}$ & MS/MS & Compound \\
\hline 1 & 1.1 & - & $\mathrm{C}_{12} \mathrm{H}_{20} \mathrm{O}_{11}$ & 341.1086 & 0.6 & 341: 179 & Sugar derivative \\
\hline 2 & 4.2 & 270 & $\mathrm{C}_{15} \mathrm{H}_{14} \mathrm{O}_{7}$ & 305.0657 & 3.2 & $\begin{array}{c}305: 261,221 \\
219,179,167,165\end{array}$ & Gallocatechin \\
\hline 3 & 8.6 & 270 & $\mathrm{C}_{15} \mathrm{H}_{14} \mathrm{O}_{8}$ & 305.0660 & 2.3 & $\begin{array}{c}305: 261,221, \\
219,179,167,165\end{array}$ & Epigallocatechin \\
\hline 4 & 9.1 & 280 & $\mathrm{C}_{15} \mathrm{H}_{14} \mathrm{O}_{9}$ & 289.0709 & 3.0 & 289: 245, 205, 203 & Catechin \\
\hline 5 & 12.5 & 280 & $\mathrm{C}_{15} \mathrm{H}_{14} \mathrm{O}_{10}$ & 289.0714 & 1.3 & 289: $245,205,203$ & Epicatechin \\
\hline $6,7,8$ & $12.5 / 13.5 / 14.6$ & 278 & $\mathrm{C}_{30} \mathrm{H}_{26} \mathrm{O}_{11}$ & $561.1402 / 561.1402$ & 1.1 & $\begin{array}{c}561: 407,305 \\
177,165\end{array}$ & $\begin{array}{l}\text { Butiniflavan- } \\
\text { (epi)gallocatechin }\end{array}$ \\
\hline 9,10 & $16.1 / 17.6$ & 280 & $\mathrm{C}_{30} \mathrm{H}_{26} \mathrm{O}_{10}$ & $545.1453 / 545.1445$ & 0.7 & $545: 391,289,245$ & Butiniflavan-(epi)catechin \\
\hline 11 & 18 & $289 / 321$ & $\mathrm{C}_{14} \mathrm{H}_{12} \mathrm{O}_{4}$ & 243.0662 & 0.3 & 243: 201,159 & Piceatannol \\
\hline $\begin{array}{l}12,13,14, \\
15\end{array}$ & $19.6 / 20 / 20.4 / 20.7$ & 280 & $\mathrm{C}_{30} \mathrm{H}_{26} \mathrm{O}_{10}$ & 545.1441 & 2.3 & $545: 305,239,165$ & $\begin{array}{l}\text { Cassiaflavan- } \\
\text { (epi)gallocatechin }\end{array}$ \\
\hline $\begin{array}{l}16,17,18 \\
19,20\end{array}$ & $22.2 / 22.7 / 23.2 / 23.5 / 24.9$ & 280 & $\mathrm{C}_{30} \mathrm{H}_{26} \mathrm{O}_{9}$ & 529.1488 & 3.0 & $\begin{array}{c}529: 289,245 \\
239,203\end{array}$ & Cassiaflavan-(epi)catechin \\
\hline 21 & 36.1 & $279 / 320 / 406$ & $\mathrm{C}_{34} \mathrm{H}_{34} \mathrm{O}_{12}$ & 633.1992 & 2.2 & $\begin{array}{c}633: 615,597 \\
579,557,555 \\
539,317,299 \\
298,259\end{array}$ & $\begin{array}{c}\text { Dimeric } \\
\text { tetrahydroanthracene } \\
\text { derivative }\end{array}$ \\
\hline
\end{tabular}

3.3. Effects of ESVR on B16F10-Nex2 Cells. Figure 3 shows the effects of different ESVR concentrations on B16F10-Nex2 cell viability and morphology after $24 \mathrm{~h}$ of treatment. At images of the 25 to $60 \mu \mathrm{g} / \mathrm{mL}$ of the extract concentration, a reduction in the cell number was observed without changing the morphology of unaffected cells that remain attached to the extracellular matrix present at the well. On the other hand, cells treated with doses equal or higher than $70 \mu \mathrm{g} / \mathrm{mL}$ of the extract showed a marked reduction in the cell number and strongly modified morphology of the remaining cells with loose attachment to the extracellular matrix.

3.4. Cell Death Profile. Cells were incubated with ESVR diluted in culture media at IC $_{50}$ without annexin V-FITC or 


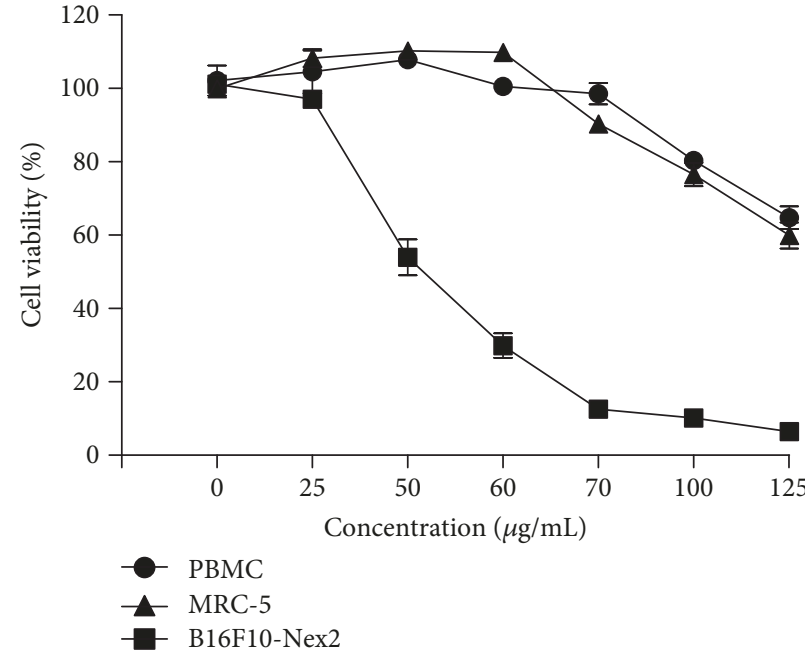

(a)

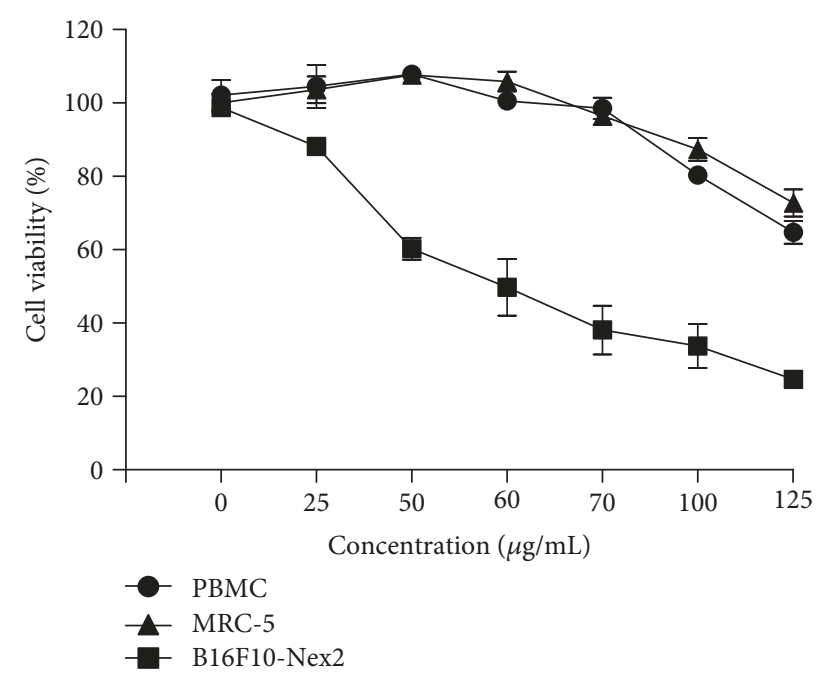

(b)

FIgURE 2: The cytotoxic effect of ESVR on PBMC, MRC-5, and B16F10-Nex2 cells treated with different ESVR concentrations for (a) 24 and (b) $48 \mathrm{~h}$. The data are expressed as the means \pm SEM in three independent experiments in triplicate.

propidium iodide. However, the fluorescence of the extract was similar to that of the markers, thereby precluding the correct interpretation of these tests (data not shown).

3.5. Apoptotic B16F10-Nex2 Cell Count. Nuclear morphological changes are characteristic of apoptotic cell death and can be determined by microscopy using specific fluorescence markers. In these analyses, the number of apoptotic B16F10-Nex2 cells treated with ESVR $(52 \mu \mathrm{g} / \mathrm{mL})$ counted under confocal microscopy shows that the extract promoted nuclear damage in $32.4 \%$ of cells, whereas only $5.2 \%$ of untreated cells were damaged (Figure 4). Only nuclei that showed extreme chromatin condensation, DNA fragmentation, and high fluorescence intensity were considered apoptotic nuclei.

3.6. DNA Fragmentation. Compounds that activate cell death pathways such as apoptosis are able to induce DNA degradation. The DNA fragmentation data shown in Figure 5 demonstrate that ESVR-treated B16F10-Nex2 cells show time-dependent DNA fragmentation, which is observed after $12 \mathrm{~h}$ and is intensified after $24 \mathrm{~h}$ and $48 \mathrm{~h}$ of treatment. After these incubation periods, the control cells showed no sign of DNA fragmentation.

3.7. Caspase-3 Activity. Caspase-3 is an effector caspase that plays a central role in the execution phase of apoptosis. Caspase- 3 activation was assessed to identify the possible cell death pathways activated by ESVR in melanoma cells. In this assay, Figure 6(a) shows right-shifted fluorescence values, thus confirming caspase- 3 activation and indicating apoptosisinduced cell death. The increase in cleaved caspase- 3 in ESVR-treated B16F10-Nex2 cells was twice as high as that in control cells (Figure 6(b)).

3.8. Determination of the Reactive Oxygen Species (ROS) Levels. ROS were evaluated in this study to verify whether they were involved in ESVR-induced cell death. The levels of ROS increased in ESVR-treated cells, as shown by the right-shifted fluorescence values (Figure $7(\mathrm{a})$ ). The mean values obtained in the fluorescence intensity were $24.271 \pm$ 4.309 for treated cells with ESVR and $2.787 \pm 408$ for the control cells (Figure 7(b)). The ROS levels increased 8.7-fold in B16F10-Nex2 cells treated with the extract after $24 \mathrm{~h}$ of incubation compared with control cells without treatment.

3.9. Pan-Caspase, Intracellular Calcium, and Necrostatin-1 Inhibition. Aiming to identify cell death modalities induced by ESVR in B16F10-Nex2 cells, different markers of apoptosis and necrosis were analyzed. Figure 8 shows that neither control B16F10-Nex2 cells nor the B16F10-Nex2 cells treated with only the inhibitors showed changes in cell viability. Conversely, cells treated with ESVR $(52 \mu \mathrm{g} / \mathrm{mL})$ for $24 \mathrm{~h}$ showed $52.0 \pm 3.3 \%$ viable cells. This result was partially reversed in the presence of the inhibitors Z-VAD-FMS $(77.9 \pm 1.4 \%), \quad$ BAPTA-AM $(73.7 \pm 3.1 \%)$, and NEC-1 $(66.7 \pm 1.2 \%)$.

3.10. Cell Cycle Phases. Cell cycle control in tumor cells is considered an important therapeutic target for the treatment of cancer. Thus, demonstrating the effects of the extract on the progression of the cell cycle will contribute to a better understanding of its mechanisms of action. Figure 9(a) shows histograms of the cell cycle distribution of control B16F10Nex2 cells and B16F10-Nex2 cells treated with $1 / 2 \mathrm{IC}_{50}=26$ $\mu \mathrm{g} / \mathrm{mL}$ and $\mathrm{IC}_{50}=52 \mu \mathrm{g} / \mathrm{mL}$ ESVR for $24 \mathrm{~h}$. The control cells and cells treated with $26 \mu \mathrm{g} / \mathrm{mL}$ of ESVR showed no differences in cell cycle distribution (Figure 9(b)). The comparison between cells treated with $52 \mu \mathrm{g} / \mathrm{mL}$ of ESVR and control cells shows that ESVR promoted cell cycle arrest at the $\mathrm{G}_{0} / \mathrm{G}_{1}$ phase $\left(54.3 \pm 3.8 \%\right.$ versus $\left.42.3 \pm 2.6 \%,{ }^{*} p<0.05\right)$ and decreased the percentage of $S$ phase cells $(22.5 \pm 2.2 \%$ versus $\left.36.6 \pm 4.2 \%,{ }^{*} p<0.05\right)$ without changing the number of cells in the $G_{2} / M$ phase $(19.9 \pm 0.8 \%$ versus $20.9 \pm 2.4 \%)$ (Figure 9(b)). 


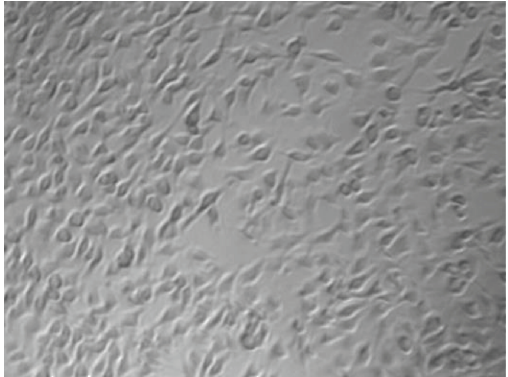

Control

(a)

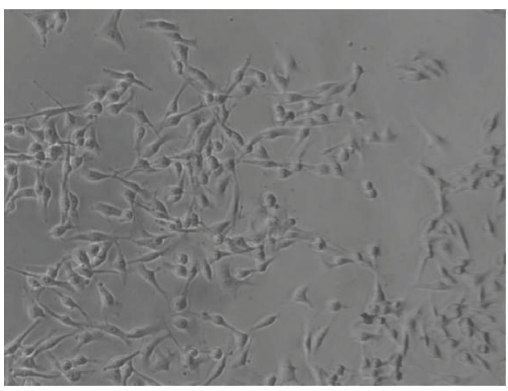

$60 \mu \mathrm{g} / \mathrm{mL}$

(d)

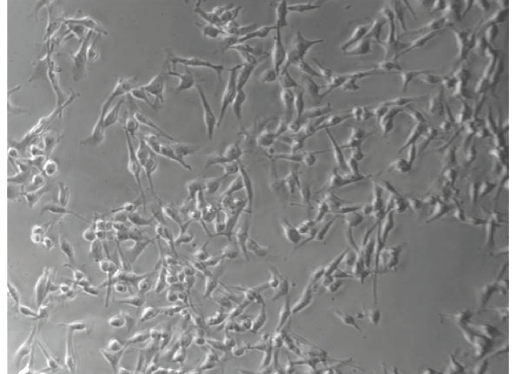

$25 \mu \mathrm{g} / \mathrm{mL}$

(b)

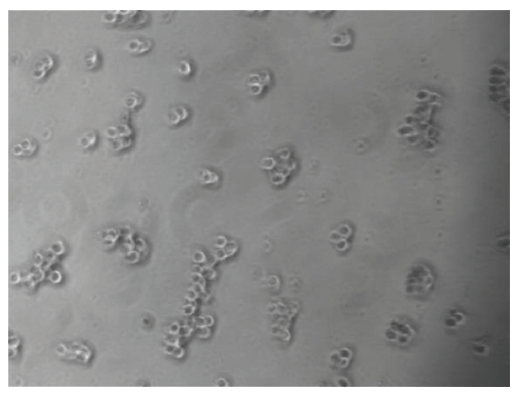

$70 \mu \mathrm{g} / \mathrm{mL}$

(e)

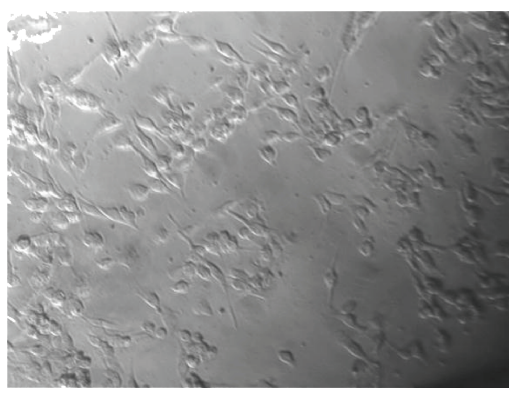

$50 \mu \mathrm{g} / \mathrm{mL}$

(c)

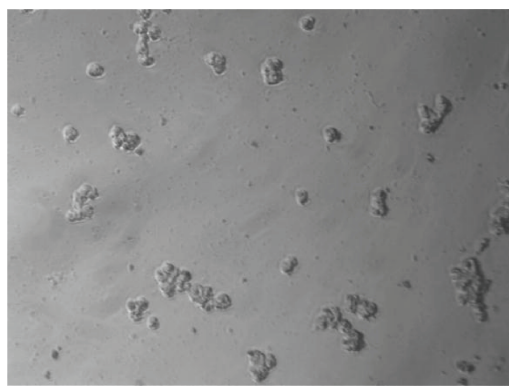

$100 \mu \mathrm{g} / \mathrm{mL}$

(f)

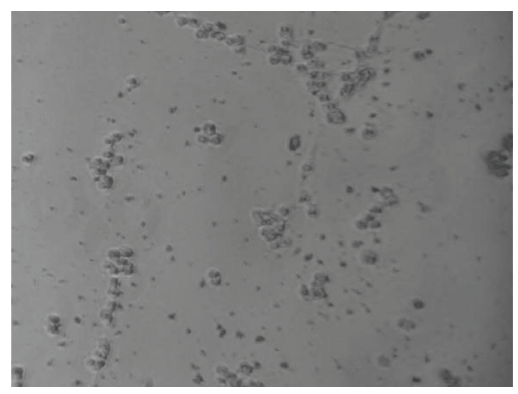

$125 \mu \mathrm{g} / \mathrm{mL}$

(g)

FIGURE 3: Reduced viability of B16F10-Nex2 cells treated with different ESVR concentrations for $24 \mathrm{~h}$. Images are representative of those seen from at least three such fields of view per sample and three independent replicates.

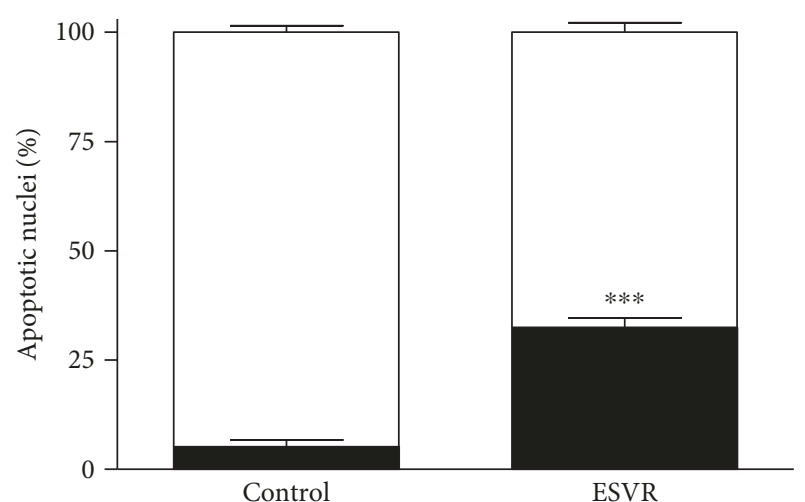

Figure 4: Count of apoptotic nuclei in B16F10-Nex2 cells treated for $24 \mathrm{~h}$ with $52 \mu \mathrm{g} / \mathrm{mL}$ of ESVR. The data are expressed as the means \pm SEM of four independent experiments in duplicate. ${ }^{* * *} p<0.001$ compared with control cells.
3.11. In Vivo Effect of ESVR on the Tumor Volume. After observing that ESVR had a cytotoxic effect on B16F10Nex2 cells in vitro, we next evaluated the effect of the extract in vivo during tumor progression. ESVR treatment of B16F10-Nex2-inoculated mice significantly delayed subcutaneous tumor development in all animals analyzed (Figure 10(a)). Figure 10(b) shows that the mean tumor volume of mice 30 days after the treatment was $57.5 \%$ smaller than the tumor volume of the control mice.

3.12. In Vivo Effect of ESVR on Pulmonary Metastasis. Next, we analyzed the effect of ESVR on metastatic B16F10-Nex2 cells developing in the lungs after endovenous inoculation at the caudal vein. It was observed that ESVR-treated animals showed $119 \pm 25$ pulmonary melanotic nodules 14 days after cell inoculation, while the control group showed $286 \pm 6$ pulmonary nodules, a 54\% reduction (Figure 11). 


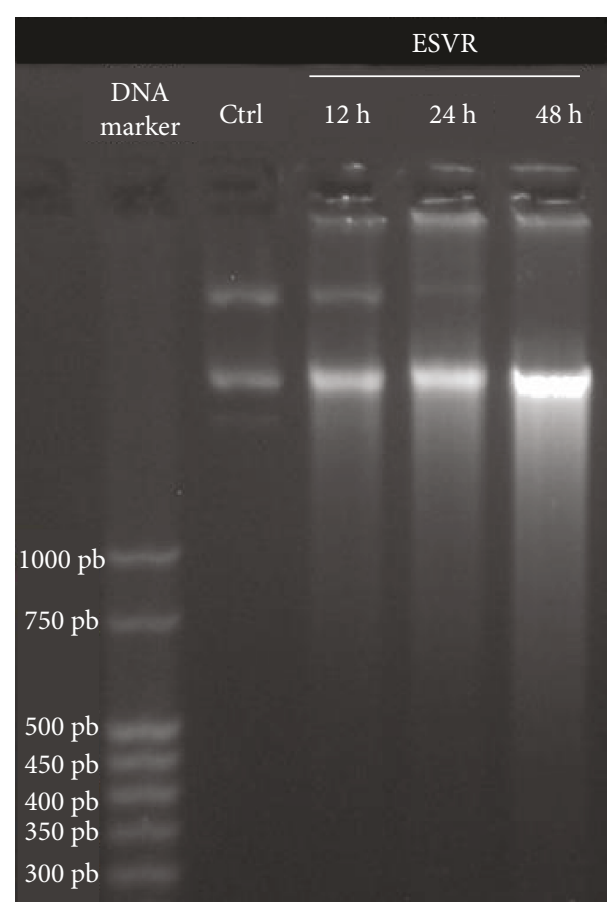

Figure 5: DNA fragmentation in B16F10-Nex2 cells analyzed by agarose gel electrophoresis after $12 \mathrm{~h}, 24 \mathrm{~h}$, and $48 \mathrm{~h}$ of treatment with $52 \mu \mathrm{g} / \mathrm{mL}$ of ESVR. Ctrl=B16F10-Nex2 cells after $48 \mathrm{~h}$ without treatment with ESVR.

\section{Discussion}

The search for new anticancer drugs with greater selectivity and lower adverse effects is an ongoing process. Natural compounds are among the alternatives that stand out as promising sources of new molecules with pharmacological potential. Accordingly, several anticancer drugs of natural origin are available on the market [31]. In this context, scientific studies have shown that Brazilian biodiversity due to its various biomes provides various natural compounds with anticancer potential both in vitro $[32,33]$ and in vivo $[30,34]$. In the present study, we assessed the anticancer effects of the ethanolic extract of the roots of $S$. velutina, a plant species native to Brazil whose phytochemical composition and potential pharmacological applications have been poorly studied.

Phytochemical analysis of ESVR identified its main compounds as flavonoid derivatives of the catechin and piceatannol (active metabolite of resveratrol) groups as well as dimeric tetrahydroanthracene derivatives. These phenolic compounds derived from plant secondary metabolism exhibit great structural diversity and are responsible for innumerable biological activities, including anticancer properties $[35,36]$.

The assessment of the effect of ESVR on B16F10-Nex2 melanoma cell viability revealed a dose-dependent death profile. This effect was confirmed by microscopy, as shown by the activity of the extract at different concentrations. In addition, ESVR showed higher selectivity against B16F10-Nex2 cells than against human leukocytes (PBMC) or human fibroblasts (MRC5). This result is highly relevant because systemic

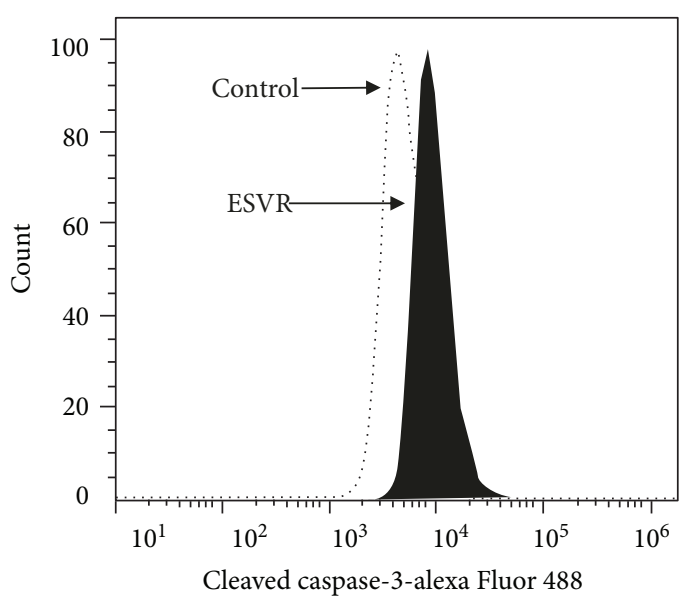

(a)

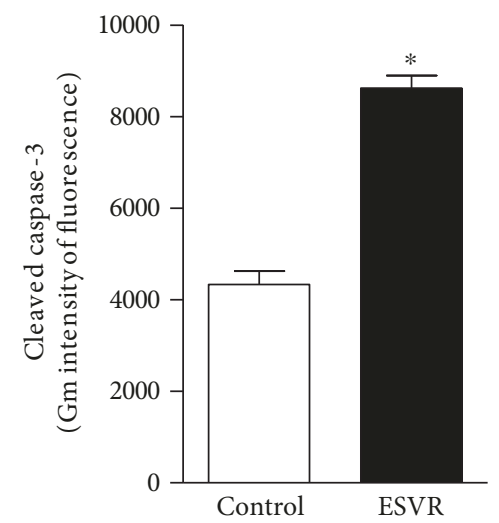

(b)

Figure 6: Caspase-3 activation by ESVR after $24 \mathrm{~h}$ represented in a histogram (a) and bar graph (b). The data are expressed as the means \pm SEM of three independent experiments in duplicate. ${ }^{*} p<0.05$ compared with control cells.

collateral effects from chemotherapeutic agent activity are a consequence of reduced selectivity against tumor cells.

The ability of the extract to promote the death of melanoma cells may be related to the isolated or synergistic effects of its chemical constituents, since the main constituents and chemical classes identified in the ESVR are well described in the literature for their antitumor activities. Catechins are described by the ability to reduce the viability of breast carcinoma cells [37] and to promote the cytotoxic effect in B16F10 murine melanoma cells [38]. Anthraquinone compounds have been reported as promising therapeutic agents for the treatment of malignant melanoma for presenting high cytotoxicity against different malignant melanoma cells and low toxicity to melanocytes and other primary cell [39]. Piceatannol, defined as a promising therapeutic agent for the treatment of various cancers, inhibited growth and induced apoptosis in human melanoma cell lines [40].

Different studies report that catechins [41, 42], anthraquinones [39], and piceatannol [43, 44] induce apoptosis in tumor cells. Corroborating this is the analysis of the mechanism whereby ESVR-promoted B16F10-Nex2 cell death showed an increased number of apoptotic nuclei, which are 


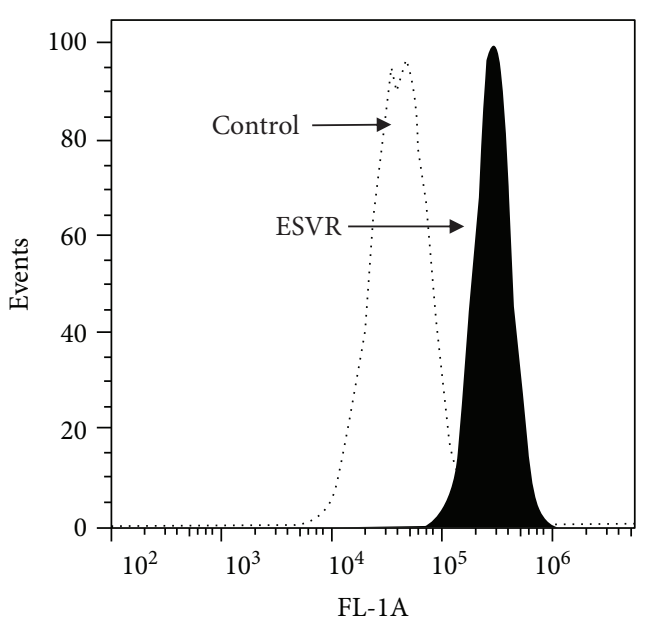

(a)

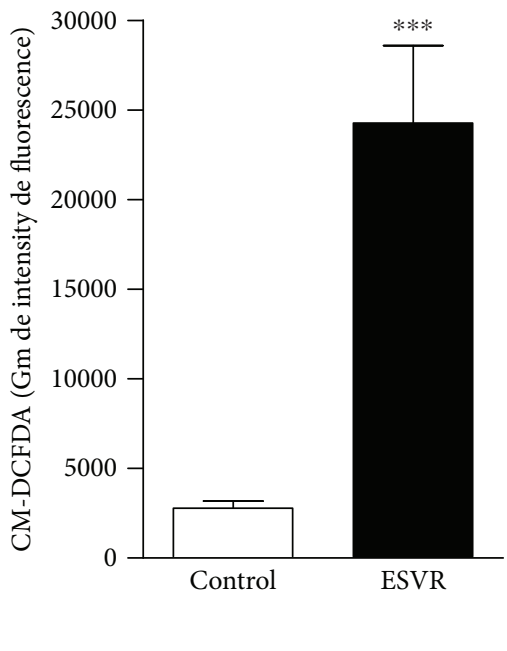

(b)

FIGURE 7: Determination of the levels of ROS in B16F10-Nex2 cells treated for $24 \mathrm{~h}$ with $52 \mu \mathrm{g} / \mathrm{mL}$ of ESVR, represented in a histogram (a) and bar graph (b). The data are expressed as the means \pm SEM of three independent experiments in duplicate. ${ }^{* * *} p<0.001$ compared with control cells.

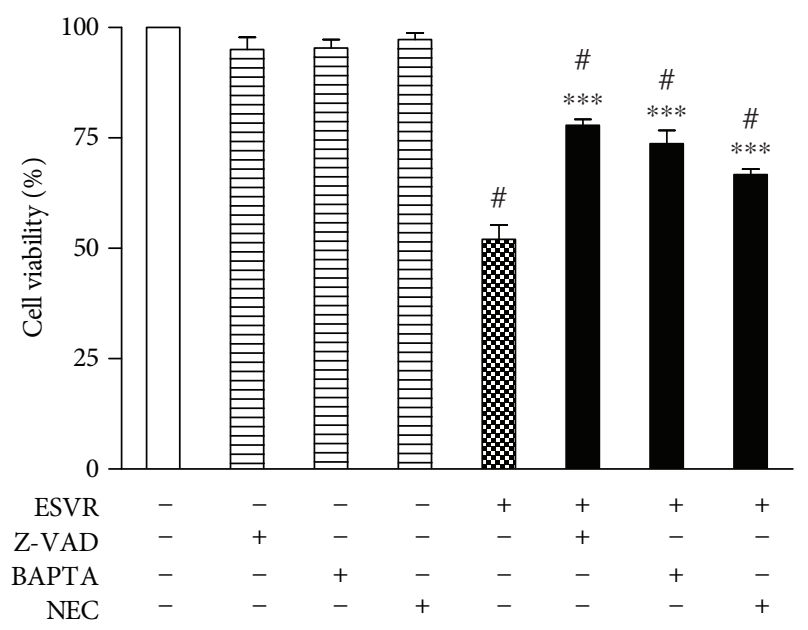

Figure 8: Effect of pan-caspase (Z-VAD-FMK), intracellular calcium channels (BAPTA-AM), and necrostatin-1 (NEC) inhibitors on B16F10-Nex2 cells treated or untreated for $24 \mathrm{~h}$ with ESVR at a concentration of $52 \mu \mathrm{g} / \mathrm{mL}$. The data are expressed as the means \pm SEM of three independent experiments in duplicate. ${ }^{\#} p<0.05$ compared with negative control cells and ${ }^{* * *} p<0.001$ compared with ESVR-treated cells.

characterized by chromatin condensation and DNA fragmentation, characteristic stages of death by apoptosis [45]. Apoptosis is considered a cell death process essential to homeostasis, mainly activated by extrinsic and intrinsic pathways [46]. In the extrinsic pathway, apoptotic receptors promote extracellular signaling. Conversely, in the intrinsic pathway, activation occurs in response to intracellular damage mediated by the mitochondria [47], a process characterized by the release of proapoptotic proteins into the cytosol, thereby promoting caspase activation and nuclear apoptosis.
Caspases are essential apoptotic cell death mediators [48]. Among these proteases, caspase- 3 is one of the main effectors of programmed cell death because it is directly involved in nuclear apoptosis and cell death [49]. In this study, ESVR-treated B16F10-Nex2 cells showed doubled activated caspase- 3 levels. In addition, the pan-caspase inhibitor Z-VAD-FMK reduced the percentage of cell death, thus demonstrating the involvement of caspases in the mechanism of cell death promoted by the extract.

Assessment of the activity of inhibitors showed that calcium and the necroptosis pathway are among the mechanisms involved in ESVR-induced cell death. High cytoplasmic $\mathrm{Ca}^{2+}$ levels are responsible for mitochondrial membrane permeabilization with cytochrome $\mathrm{c}$ release, thereby enhancing the signs of apoptosis [50-52].

Necroptosis is a form of cell death that shows characteristics of necrosis, but unlike necrosis, it may be regulated by receptor-interacting proteins 1 (RIP1) and 3 (RIP3) [53]. Furthermore, recent studies show that oxidative stress may promote necroptosis activation $[54,55]$. Although necroptosis is not the main mechanism of death characterized by the action of ESVR, this finding is interesting, one which can be an alternative form of cell death to populations of cells exhibiting resistance to death by apoptosis.

Conversely, cancer cells also have a persistent prooxidative state and high ROS levels [56]. This different metabolism promotes an adaptive response that plays a key role in cancer cell proliferation, cell death signaling disruption, metastasis, and resistance to antitumor drugs $[57,58]$. Nevertheless, cancer cells become vulnerable to prooxidant agents that further increase ROS levels, thus promoting cell death [56].

Some flavonoids, the main compounds of ESVR, are described in the literature as prooxidant agents in cancer cells $[41,59]$ because they can directly increase ROS production, resulting in superoxide radical formation [60], a mechanism 


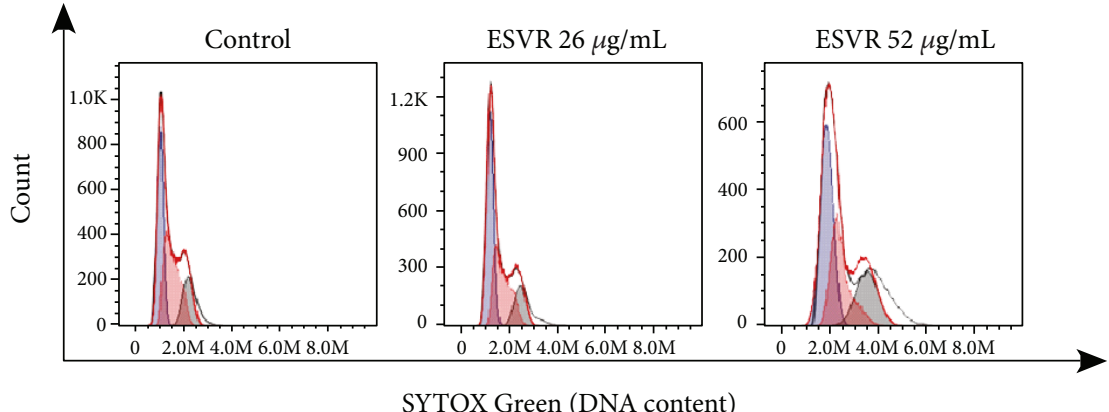

(a)

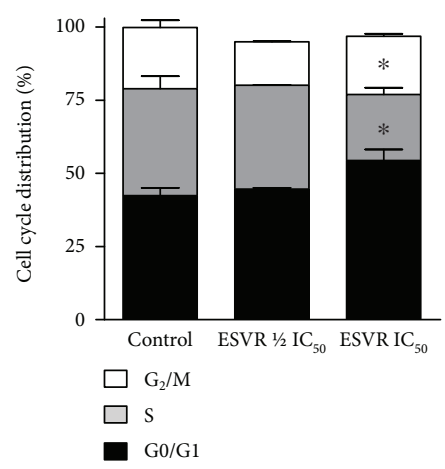

(b)

Figure 9: Histograms (a) and a bar graph (b) representative of the cell cycle distribution of control (untreated) B16F10-Nex2 cells and B16F10-Nex2 cells treated for $24 \mathrm{~h}$ with $1 / 2 \mathrm{IC}_{50}=26 \mu \mathrm{g} / \mathrm{mL}$ and $\mathrm{IC}_{50}=52 \mu \mathrm{g} / \mathrm{mL}$ ESVR. The data are expressed as the means \pm SEM of four independent experiments. ${ }^{*} p<0.05$ compared with control cells.

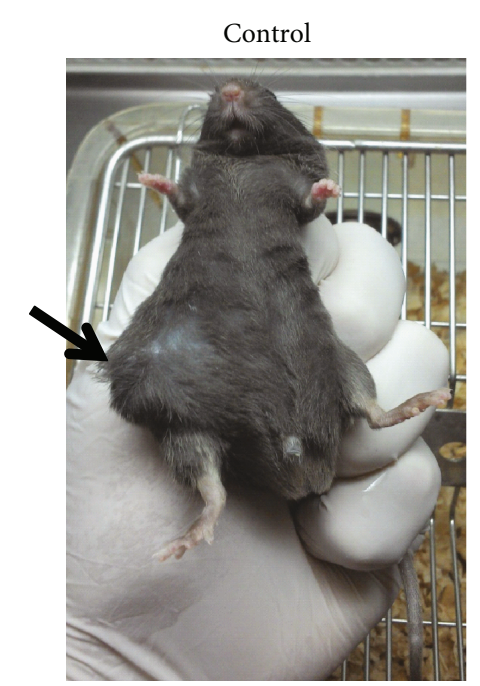

(a)

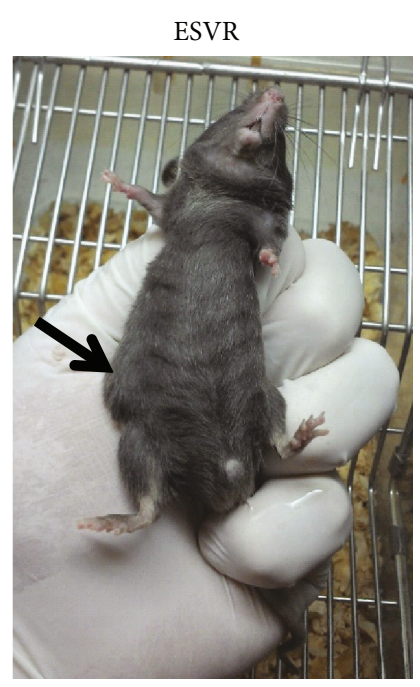

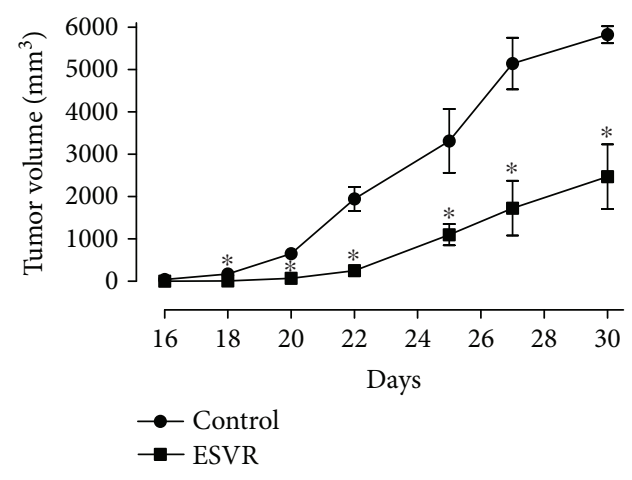

(b)

FIGURE 10: The effect of ESVR on the tumor volume of B16F10-Nex2 cells induced in C57Bl-6 mice. Representative images of 30-day tumors (arrows) in (a) control animals treated with RPMI 1640 medium and animals treated with ESVR. (b) A representative plot of tumor volume progression during 30 days of treatment. The data are expressed as the means \pm SEM $(n=7) .{ }^{*} p<0.05$ compared with the control group.
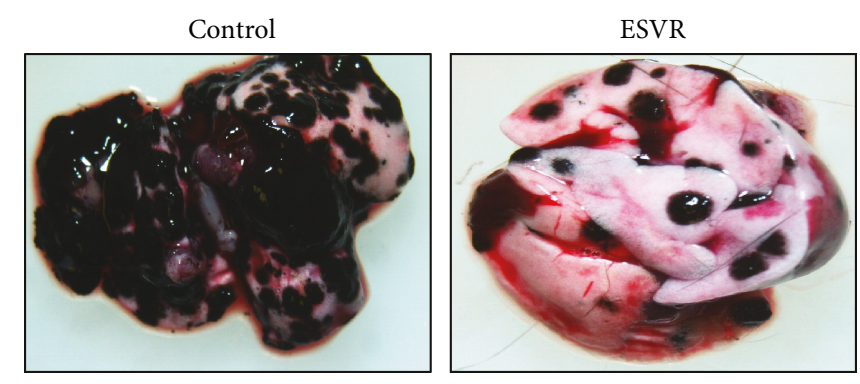

(a)

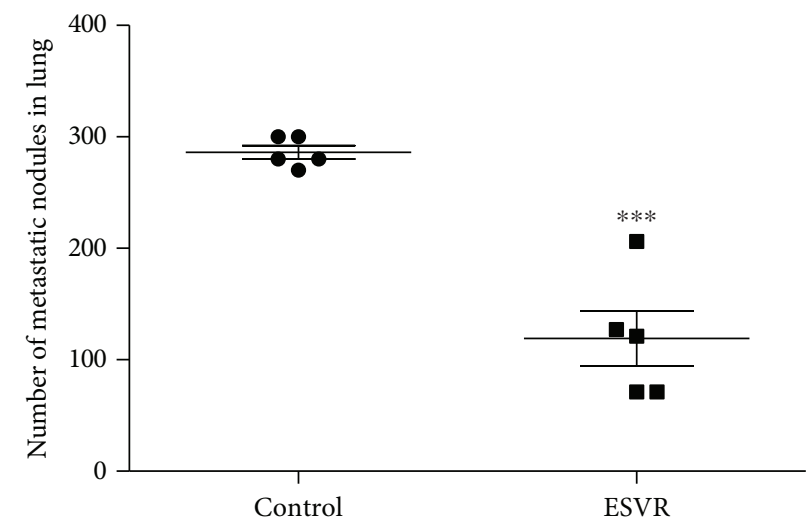

(b)

FIGURE 11: The effect of ESVR on the pulmonary metastasis of B16F10-Nex2 cells induced in C57Bl/6 mice. Representative lung images of (a) control animals treated with RPMI 1640 and animals treated with ESVR. (b) A graph representing the number of pulmonary metastasis in all animals after 14 days of endogenous cell inoculation. The data are expressed as the means $\pm \operatorname{SEM}(n=5)$. ${ }^{* * *} p<0.001$ compared with the control group. 
whereby ESVR may have contributed to B16F10-Nex2 cell death because the intracellular ROS levels were high. Furthermore, anthracene derivatives, another group of compounds identified in ESVR, are described for inducing apoptosis by increasing ROS production [54].

Another activity promoted by the extract was cell cycle arrest at the sub- $G_{0} / G_{1}$ phase, accompanied by a decrease in the percentage of $S$ phase cells. Some flavonoids, such as catechins, can cause cell cycle arrest at the $G_{0} / G_{1}$ phase of the cell cycle $[55,61]$. Piceatannol decreases cyclindependent kinase 1 (CDK1), which is responsible for cell cycle progression from the $G_{1}$ phase to the $S$ phase [62]. Thus, considering the importance of the cyclin-dependent kinases involved in cell cycle regulation and the uncontrolled cell proliferation in tumor cells, compounds capable of inhibiting the cell cycle progression of these cells may be important alternatives for tumor volume control $[63,64]$.

In this study, after confirmed in vitro antitumor action in B16F10-Nex2 murine melanoma cells, we demonstrated that ESVR produces antitumor activity on tumor volume progression and pulmonary nodule formation in vivo. Our data from in vivo antitumor assessment showed that primary tumor progression in ESVR-treated mice decreased by more than $50 \%$ compared with control mice. Cutaneous melanoma is one of the most aggressive forms of cancer, and no fully effective pharmacological therapy for advanced-stage metastatic melanoma is currently available $[65,66]$. In these cases, metastases are responsible for the poor prognosis [67], affecting several organs, such as the bones, liver, and lungs [68]. The progression of pulmonary metastasis in ESVR-treated mice was markedly reduced, as observed in the formation of pulmonary nodules. This result may be related to the ability of the extract to reduce the migration and invasion of melanoma cells into the lungs. These effects may be related to the chemical constituents of ESVR, since epigallocatechin (one of the identified catechins), anthraquinones, and resveratrol (precursor molecule of piacetannol) are compounds reported to inhibit tumor growth [69-71] and progression of pulmonary metastasis [70] in animal models for melanoma. In addition, phenolic compounds are well described because they hamper metastasis by decreasing metalloprotease- 9 expression in murine melanoma cells [72, 73]. Moreover, other studies showed that epigallocatechin can inhibit genes that synthesize proteins related to extracellular matrix degradation and cellular mobility, thereby reducing the process of melanoma metastasis [74].

In conclusion, this study demonstrated that ESVR contains flavonoid derivatives of catechins, anthraquinones, and piceatannol among its chemical constituents and promotes B16F10-Nex2 melanoma cell death via apoptosis induced by caspase- 3 activation, the elevation of intracellular calcium and ROS levels, and cell cycle arrest at the $\mathrm{G}_{0} / \mathrm{G}_{1}$ phase. Furthermore, the extract showed in vivo antitumor activity in models of primary tumor volume progression and pulmonary nodule formation. These promising results open the door for further studies, both with the crude extract and with fractions isolated from Senna velutina roots, exploring its potential use in the treatment of melanoma and other cancers.

\section{Data Availability}

The experimental data used to support the findings of this study are included within the article.

\section{Conflicts of Interest}

The authors declare that there are no conflicts of interest.

\section{Acknowledgments}

This work was supported by grants from Fundação de Apoio ao Desenvolvimento do Ensino, Ciência e Tecnologia do Estado de Mato Grosso do Sul (FUNDECT); Coordenação de Aperfeiçoamento de Pessoal de Nível Superior (CAPES); and Conselho Nacional de Desenvolvimento Científico e Tecnológico (CNPq).

\section{Supplementary Materials}

Figure S1: the cytotoxic effect of ESVR on human melanoma cell lines SK-Mel-28 and SK-Mel-103 treated with different concentrations for (A) $24 \mathrm{~h}$ and (B) $48 \mathrm{~h}$. The data are expressed as the means \pm SEM in three independent experiments in triplicate. (Supplementary Materials)

\section{References}

[1] GBD 2015 Mortality and Causes of Death Collaborators, "Global, regional, and national life expectancy, all-cause mortality, and cause-specific mortality for 249 causes of death, 19802015: a systematic analysis for the global burden of disease study 2015," The Lancet, vol. 388, no. 10053, pp. 1459-1544, 2016.

[2] M. Eggermont, A. Spatz, and C. Robert, "Cutaneous melanoma," The Lancet, vol. 383, no. 9919, pp. 816-827, 2014.

[3] B. C. Bastian, "The molecular pathology of melanoma: an integrated taxonomy of melanocytic neoplasia," Annual Review of Pathology: Mechanisms of Disease, vol. 9, no. 1, pp. 239-271, 2014.

[4] D. C. Whiteman, C. A. Whiteman, and A. C. Green, "Childhood sun exposure as a risk factor for melanoma: a systematic review of epidemiologic studies," Cancer Causes and Control, vol. 12, no. 1, pp. 69-82, 2001.

[5] S. Gandini, F. Sera, M. S. Cattaruzza et al., "Meta-analysis of risk factors for cutaneous melanoma: III. Family history, actinic damage and phenotypic factors," European Journal of Cancer, vol. 41, no. 14, pp. 2040-2059, 2005.

[6] World Health Organization, "Skin cancers: how common is skin cancer," 2018, http://www.who.int/uv/faq/skincancer/en/ index1.html.

[7] F. Erdmann, J. Lortet-Tieulent, and J. Schuz, "International trends in the incidence of malignant melanoma 19532008-are recent generations at higher or lower risk?," Internacional Journal of Cancer, vol. 132, no. 2, pp. 385-400, 2013.

[8] H. Tsao, M. B. Atkins, and A. J. Sober, "Management of cutaneous melanoma," The New England Journal of Medicine, vol. 351, no. 10, pp. 998-1012, 2004.

[9] M. Patel, E. Smyth, P. B. Chapman et al., "Therapeutic implications of the emerging molecular biology of uveal melanoma," Clinical Cancer Research, vol. 17, no. 8, pp. 20872100, 2011. 
[10] A. M. Eggermont and C. Robert, "New drugs in melanoma: it's a whole new world," European Journal of Cancer, vol. 47, no. 14, pp. 2150-2157, 2011.

[11] T. Kim, R. N. Amaria, C. Spencer, A. Reuben, Z. A. Cooper, and J. A. Wargo, "Combining targeted therapy and immune checkpoint inhibitors in the treatment of metastatic melanoma," Cancer Biology \& Medicine, vol. 11, no. 4, pp. 237246, 2014.

[12] B. S. Kalal, D. Upadhya, and V. R. Pai, "Chemotherapy resistance mechanisms in advanced skin Cancer," Oncology Reviews, vol. 11, no. 1, p. 326, 2017.

[13] L. R. Strickland, H. C. Pal, C. A. Elmets, and F. Afaq, “Targeting drivers of melanoma with synthetic small molecules and phytochemicals," Cancer Letters, vol. 359, no. 1, pp. 20-35, 2015.

[14] S. J. Chatterjee and S. Pandey, "Chemo-resistant melanoma sensitized by tamoxifen to low dose curcumin treatment through induction of apoptosis and autophagy," Cancer Biology \& Therapy, vol. 11, no. 2, pp. 216-228, 2011.

[15] A. Ghorbani and A. Hosseini, "Cancer therapy with phytochemicals: evidence from clinical studies," Avicenna Journal of Phytomedicine, vol. 5, no. 2, pp. 84-97, 2015.

[16] E. Solowey, M. Lichtenstein, S. Sallon, H. Paavilainen, and H. Lorberboum-Galski, "Evaluating medicinal plants for anticancer activity," The Scientific World Journal, vol. 2014, Article ID 721402, 12 pages, 2014.

[17] D. J. Newman and G. M. Cragg, "Natural products as sources of new drugs from 1981 to 2014," Journal of Natural Products, vol. 79, no. 3, pp. 629-661, 2016.

[18] J. Clardy and C. Walsh, "Lessons from natural molecules," Nature, vol. 432, no. 7019, pp. 829-837, 2004.

[19] S. L. Jothy, A. Torey, I. Darah et al., "Cassia spectabilis (DC) Irwin et Barn: A Promising Traditional Herb in Health Improvement," Molecules, vol. 17, no. 9, pp. 10292-10305, 2012.

[20] G. K. Varghese, L. V. Bose, and S. Habtemariam, “Antidiabetic components of Cassia alata leaves: identification through $\alpha$-glucosidase inhibition studies," Pharmaceutical Biology, vol. 51, no. 3, pp. 345-349, 2013.

[21] M. P. Mokgotho, S. S. Gololo, P. Masoko et al., "Isolation and chemical structural characterisation of a compound with antioxidant activity from the roots of Senna italica," Evidencebased Complementary and Alternative Medicine, vol. 2013, Article ID 519174, 6 pages, 2013.

[22] A. D. C. Susunaga-Notario, S. Pérez-Gutiérrez, M. Á. ZavalaSánchez et al., "Bioassay-Guided Chemical Study of the Anti-Inflammatory Effect of Senna villosa (Miller) H.S. Irwin \& Barneby (Leguminosae) in TPA-Induced Ear Edema," Molecules, vol. 19, no. 7, pp. 10261-10278, 2014.

[23] G. Aviello, I. Rowland, C. I. Gill et al., "Anti-proliferative effect of rhein, an anthraquinone isolated from Cassia species, on Caco-2 human adenocarcinoma cells," Journal of Cellular and Molecular Medicine, vol. 14, no. 7, pp. 2006-2014, 2010.

[24] J. F. Campos, D. T. H. de Castro, M. J. Damião et al., "The chemical profile of Senna velutina leaves and their antioxidant and cytotoxic effects," Oxidative Medicine and Cellular Longevity, vol. 2016, Article ID 8405957, 12 pages, 2016.

[25] R. M. Pereira, G. Á. Ferreira-Silva, M. Pivatto et al., "Alkaloids derived from flowers of Senna spectabilis, (-)-cassine and (-)-spectaline, have antiproliferative activity on HepG2 cells for inducing cell cycle arrest in $G_{1} / S$ transition through ERK inactivation and downregulation of cyclin D1 expression," Toxicology In Vitro, vol. 31, pp. 86-92, 2016.

[26] P. T. O. Saiki, B. Silva, and C. Lomônaco, "Expression of reproductive and vegetative characters of Senna velutina (Vogel) H. S. Irwin \& Barneby (Leguminosae, Caesalpinioideae) in two distinct "cerrado" environments," Brazilian Journal of Botany, vol. 31, no. 2, pp. 363-369, 2008.

[27] S. M. Loverde-Oliveira, M. N. Freitas, P. K. B. Araújo, and I. B. C. Costa, "Fragmento de cerrado urbano da Universidade Federal de Mato Grosso, campus de Rondonópolis, Mato Grosso," Biodiversidade, vol. 9, no. 1, 2010.

[28] E. J. Paredes-Gamero, M. N. Martins, F. A. Cappabianco, J. S. Ide, and A. Miranda, "Characterization of dual effects induced by antimicrobial peptides: regulated cell death or membrane disruption," Biochimica et Biophysica Acta (BBA) - General Subjects, vol. 1820, no. 7, pp. 1062-1072, 2012.

[29] V. W. Moraes, A. C. Caires, E. J. Paredes-Gamero, and T. Rodrigues, "Organopalladium compound $7 \mathrm{~b}$ targets mitochondrial thiols and induces caspase-dependent apoptosis in human myeloid leukemia cells," Cell Death \& Disease, vol. 4, article e658, no. 6, 2013.

[30] F. V. Pereira, A. C. Melo, F. M. de Melo et al., "TLR4-mediated immunomodulatory properties of the bacterial metalloprotease arazyme in preclinical tumor models," Oncoimmunology, vol. 5, no. 7, article e1178420, 2016.

[31] B. Shen, "A new golden age of natural products drug discovery," Cell, vol. 163, no. 6, pp. 1297-1300, 2015.

[32] J. F. Campos, P. P. T. Espindola, H. F. V. Torquato et al., "Leaf and root extracts from Campomanesia adamantium (Myrtaceae) promote apoptotic death of leukemic cells via activation of intracellular calcium and caspase-3," Frontiers in Pharmacology, vol. 8, no. 8, article 466, 2017.

[33] T. Bonamigo, J. F. Campos, A. S. Oliveira et al., “Antioxidant and cytotoxic activity of propolis of Plebeia droryana and Apis mellifera (Hymenoptera, Apidae) from the Brazilian Cerrado biome," PLoS One, vol. 12, no. 9, p. e0183983, 2017.

[34] G. B. Longato, L. Y. Rizzo, I. M. Sousa et al., "In vitro and in vivo anticancer activity of extracts, fractions, and eupomatenoid-5 obtained from Piper regnellii leaves," Planta Medica, vol. 77, no. 13, pp. 1482-1488, 2011.

[35] W. Y. Huang, Y. Z. Cai, and Y. Zhang, "Natural phenolic compounds from medicinal herbs and dietary plants: potential use for cancer prevention," Nutrition and Cancer, vol. 62, no. 1, pp. 1-20, 2010.

[36] S. Gorlach, J. Fichna, and U. Lewandowska, "Polyphenols as mitochondria-targeted anticancer drugs," Cancer Letters, vol. 366, no. 2, pp. 141-149, 2015.

[37] L. Schroder, P. Marahrens, J. G. Koch et al., "Effects of green tea, matcha tea and their components epigallocatechin gallate and quercetin on MCF-7 and MDA-MB-231 breast carcinoma cells," Oncology Reports, vol. 41, no. 1, pp. 387-396, 2018.

[38] C. C. Chen, D. S. Hsieh, K. J. Huang et al., "Improving anticancer efficacy of (-)-epigallocatechin-3-gallate gold nanoparticles in murine B16F10 melanoma cells," Drug Design Development and Therapy, vol. 8, pp. 459-474, 2014.

[39] M. Genov, B. Kreiseder, M. Nagl, E. Drucker, and e. al, "Tetrahydroanthraquinone derivative $( \pm)$-4-deoxyaustrocortilutein induces cell cycle arrest and apoptosis in melanoma cells via upregulation of p21 and p53 and downregulation of NF-kappaB," Journal of Cancer, vol. 7, no. 5, pp. 555568, 2016. 
[40] M. Du, Z. Zhang, and T. Gao, "Piceatannol induced apoptosis through up-regulation of microRNA-181a in melanoma cells," Biological Research, vol. 50, no. 1, p. 36, 2017.

[41] S. Li, L. Wu, J. Feng et al., "In vitro and in vivo study of epigallocatechin-3-gallate-induced apoptosis in aerobic glycolytic hepatocellular carcinoma cells involving inhibition of phosphofructokinase activity," Scientific Reports, vol. 6, no. 1, article 28479, 2016.

[42] K. Phuriwat, P. Pattamaphron, R. Lysiane, P. Dumrongsak, and S. Piyarat, "Epistructured catechins, EGCG and EC facilitate apoptosis induction through targeting de novo lipogenesis pathway in HepG2 cells," Cancer Cell International, vol. 18, no. 1, 2018.

[43] G. A. Potter, L. H. Patterson, E. Wanogho et al., "The cancer preventative agent resveratrol is converted to the anticancer agent piceatannol by the cytochrome P450 enzyme CYP1B1," British Journal of Cancer, vol. 86, no. 5, pp. 774-778, 2002.

[44] Y. H. Kim, C. Park, J. O. Lee et al., "Induction of apoptosis by piceatannol in human leukemic U937 cells through downregulation of Bcl-2 and activation of caspases," Oncology Reports, vol. 19, no. 4, pp. 961-967, 2008.

[45] S. Nagata, "Apoptotic DNA fragmentation," Experimental Cell Research, vol. 256, no. 1, pp. 12-18, 2000.

[46] G. Xu and Y. Shi, "Apoptosis signaling pathways and lymphocyte homeostasis," Cell Research, vol. 17, no. 9, pp. 759-771, 2007.

[47] T. Vanden Berghe, W. J. Kaiser, M. J. Bertrand, and P. Vandenabeele, "Molecular crosstalk between apoptosis, necroptosis, and survival signaling," Molecular \& Cellular Oncology, vol. 2, no. 4, article e975093, 2015.

[48] D. R. McIlwain, T. Berger, and T. W. Mak, "Caspase functions in cell death and disease," Cold Spring Harbor Perspectives in Biology, vol. 5, no. 4, article a008656, 2013.

[49] A. G. Porter and R. U. Janicke, "Emerging roles of caspase-3 in apoptosis," Cell Death \& Differentiation, vol. 6, no. 2, pp. 99104, 1999.

[50] R. Rizzuto, P. Pinton, W. Carrington et al., "Close contacts with the endo-plasmic reticulum as determinants of mitochondrial $\mathrm{Ca}^{2+}$ responses," Science, vol. 280, no. 5370, pp. 1763-1766, 1998.

[51] Y. Yan, C. L. Wei, W. R. Zhang, H. P. Cheng, and J. Liu, "Cross-talk between calcium and reactive oxygen species signaling," Acta Pharmacologica Sinica, vol. 27, no. 7, pp. 821826, 2006.

[52] C. Giorgi, A. Romagnoli, P. Pinton, and R. Rizzuto, " $\mathrm{Ca}^{2+}$ signaling, mitochondria and cell death," Current Molecular Medicine, vol. 8, no. 2, pp. 119-130, 2008.

[53] M. D'Arcy, "Cell death: A review of the major forms of apoptosis, necrosis and autophagy," Cell Biology International, 2019.

[54] S. Q. Xie, Z. Q. Zhang, G. Q. Hu, M. Xu, and B. S. Ji, "HL-37, a novel anthracene derivative, induces $\mathrm{ca}(2+)$-mediated apoptosis in human breast cancer cells," Toxicology, vol. 254, no. 1-2, pp. 68-74, 2008.

[55] G. J. Du, Z. Zhang, and X. D. Wen, "Epigallocatechin gallate (EGCG) is the most effective cancer chemopreventive polyphenol in green tea," Nutrients, vol. 4, no. 11, pp. 1679-1691, 2012.

[56] L. Gibellini, M. Pinti, M. Nasi et al., "Interfering with ROS metabolism in cancer cells: the potential role of quercetin," Cancers, vol. 2, no. 2, pp. 1288-1311, 2010.
[57] D. Trachootham, J. Alexandre, and P. Huang, "Targeting cancer cells by ROS-mediated mechanisms: a radical therapeutic approach?," Nature Review Drug Discovery, vol. 8, no. 7, pp. 579-591, 2009.

[58] L. Zhu, L. Ren, Y. Chen, J. Fang, Z. Ge, and X. Li, "Redox status of high-mobility group box 1 performs a dual role in angiogenesis of colorectal carcinoma," Journal of Cellular and Molecular Medicine, vol. 19, no. 9, pp. 2128-2135, 2015.

[59] C. Martin-Cordero, A. J. Leon-Gonzalez, J. M. CalderonMontano, E. BurgosMoron, and M. Lopez-Lazaro, "Prooxidant natural products as anticancer agents," Current Drug Targets, vol. 13, no. 8, pp. 1006-1028, 2012.

[60] W. F. Hodnick, E. B. Milosavljevic, J. H. Nelson, and R. S. Pardini, "Electrochemistry of flavonoids: Relationships between redox potentials, inhibition of mitochondrial respiration, and production of oxygen radicals by flavonoids," Biochemical Pharmacology, vol. 37, no. 13, pp. 2607-2611, 1988.

[61] I. Cordero-Herrera, M. A. Martín, L. Bravo, L. Goya, and S. Ramos, "Epicatechin gallate induces cell death via p53 activation and stimulation of $\mathrm{p} 38$ and JNK in human colon cancer SW480 cells," Nutrition and Cancer, vol. 65, no. 5, pp. 718 728, 2013.

[62] Y. M. Lee, D. Y. Lim, H. J. Cho et al., "Piceatannol, a natural stilbene from grapes, induces G1 cell cycle arrest in androgen-insensitive DU145 human prostate cancer cells via the inhibition of CDK activity," Cancer Letters, vol. 285, no. 2, pp. 166-173, 2009.

[63] W. Nam, J. Tak, J. K. Ryu et al., "Effects of artemisinin and Its derivatives on growth inhibition and apoptosis of oral cancer cells," Head \& Neck, vol. 29, no. 4, pp. 335-340, 2007.

[64] S. Diaz-Moralli, M. Tarrado-Castellarnau, A. Miranda, and M. Cascante, "Targeting cell cycle regulation in cancer therapy," Pharmacology \& Therapeutics, vol. 138, no. 2, pp. 255271, 2013.

[65] Y. Kotobuki, L. Yang, S. Serada et al., "Periostin accelerates human malignant melanoma progression by modifying the melanoma microenvironment," Pigment Cell Melanoma Research, vol. 27, no. 4, pp. 630-639, 2014.

[66] F. Zhao, X. He, J. Sun et al., "Cancer stem cell vaccine expressing ESAT-6-gpi and IL-21 inhibits melanoma growth and metastases," American Journal of Translational Research, vol. 7, no. 10, pp. 1870-1882, 2015.

[67] E. Maverakis, L. A. Cornelius, G. M. Bowen et al., "Metastatic melanoma-a review of current and future treatment options," Acta Dermato-Venereologica, vol. 95, no. 5, pp. 516-524, 2015.

[68] F. Tas, "Metastatic behavior in melanoma: timing, pattern, survival, and influencing factors," Journal of Oncology, vol. 2012, Article ID 647684, 9 pages, 2012.

[69] J. Zhang, Z. Lei, Z. Huang et al., "Epigallocatechin-3-gallate(EGCG) suppresses melanoma cell growth and metastasis by targeting TRAF6 activity," Oncotarget, vol. 7, no. 48, pp. 79557-79571, 2016.

[70] J. Xie, J. P. Yun, Y. N. Yang et al., “A novel ECG analog 4-(S)(2,4,6-trimethylthiobenzyl)-epigallocatechin gallate selectively induces apoptosis of B16-F10 melanoma via activation of autophagy and ROS," Scientific Reports, vol. 7, no. 1, article 42194, 2017.

[71] H. J. Ku, O. S. Kwon, B. S. Kang, D. S. Lee, H. S. Lee, and J. W. Park, "IDH2 knockdown sensitizes tumor cells to emodin cytotoxicity in vitro and in vivo," Free Radical Research, vol. 50, no. 10, pp. 1089-1097, 2016. 
[72] H. G. Farina, M. Pomies, D. F. Alonso, and D. E. Gomez, "Antitumor and antiangiogenic activity of soy isoflavone genistein in mouse models of melanoma and breast cancer," Oncology Reports, vol. 16, no. 4, pp. 885-891, 2006.

[73] S. J. Pradhan, R. Mishra, P. Sharma, and G. C. Kundu, "Quercetin and sulforaphane in combination suppress the progression of melanoma through the down-regulation of matrix metalloproteinase-9," Experimental and Therapeutic Medicine, vol. 1, no. 6, pp. 915-920, 2010.

[74] M. W. Roomi, T. Kalinovsky, A. Niedzwiecki, and M. Rath, "Modulation of MMP-2 and -9 secretion by cytokines, inducers and inhibitors in human melanoma A-2058 cells," Oncology Reports, vol. 37, no. 6, pp. 3681-3687, 2017. 


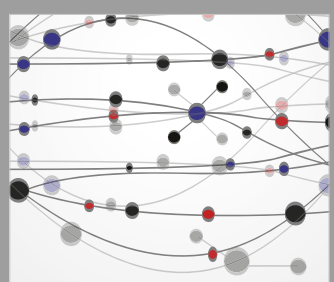

The Scientific World Journal
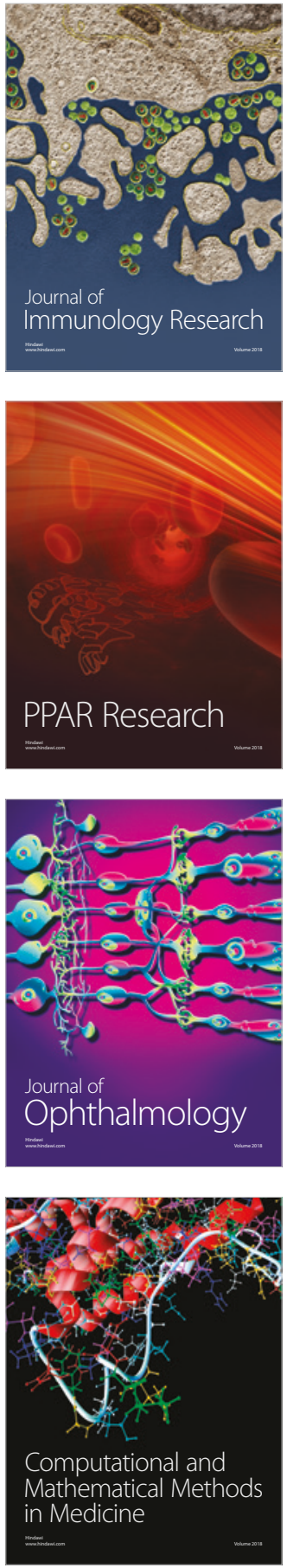

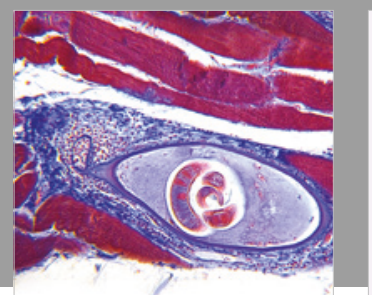

Gastroenterology Research and Practice

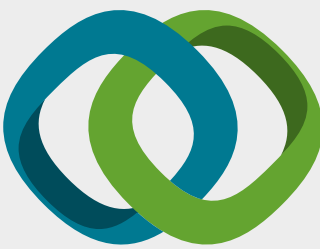

\section{Hindawi}

Submit your manuscripts at

www.hindawi.com
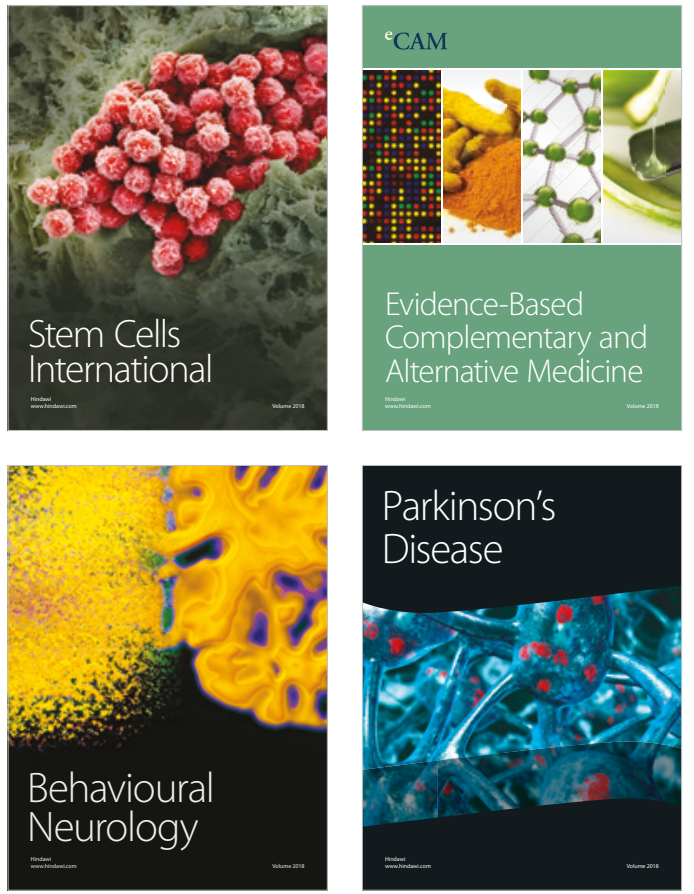

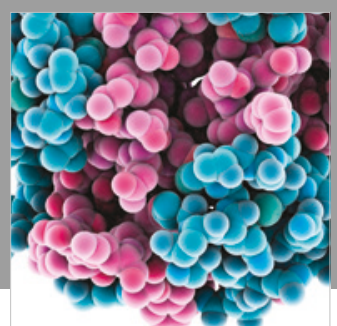

ournal of

Diabetes Research

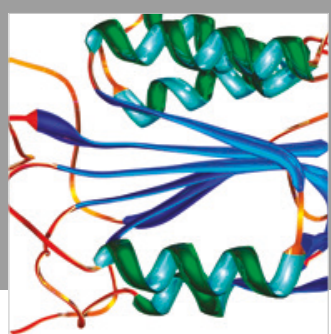

Disease Markers
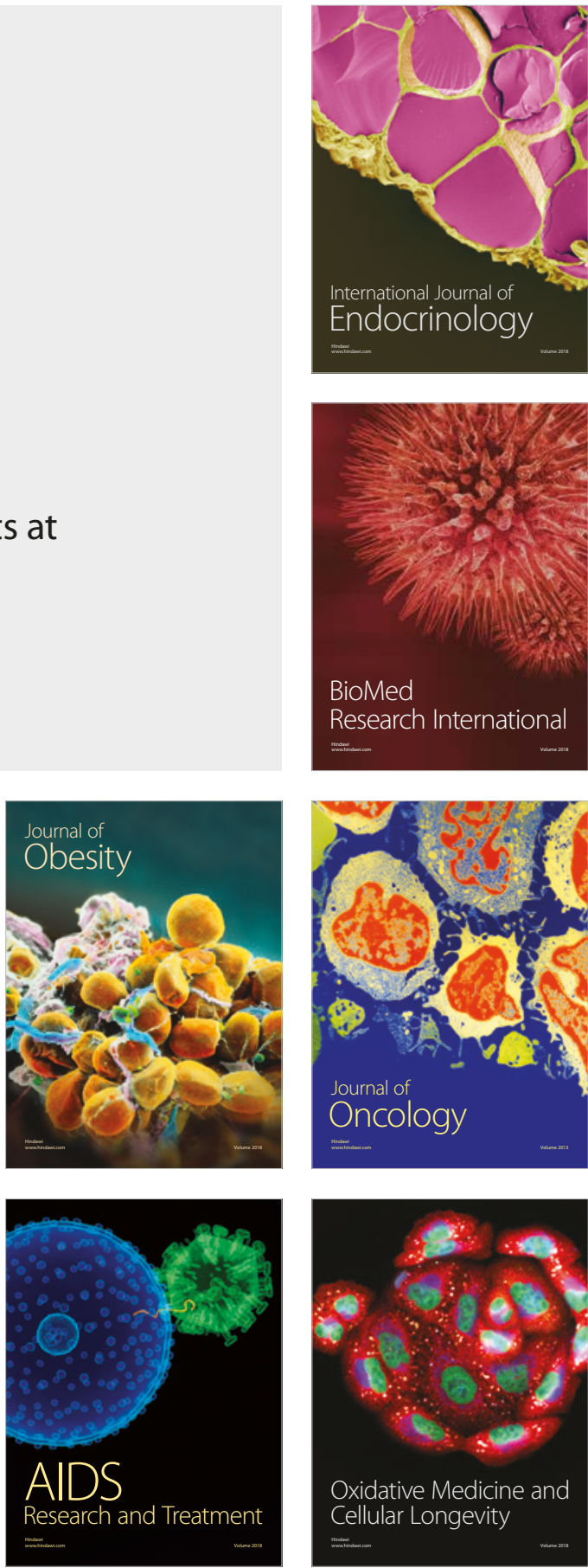